\title{
The impact of contactless payment on cash usage at an early stage of diffusion
}

\author{
Tobias Trütsch
}

\begin{abstract}
This paper explores the impact of contactless payment on consumers' demand for cash at an early stage of diffusion. The specific devices that are investigated are debit and credit cards, in which the feature is embedded. A novel balanced panel dataset drawn from representative surveys on consumer payment behavior in the USA from 2009 to 2013 is analyzed to account for unobserved heterogeneity in cash usage. The results show that contactless credit and debit cards exert no statistically significant effect on cash usage after controlling for unobserved heterogeneity. Consumers' decision to use contactless payment is an endogenous choice. Card-affined individuals replace conventional card payments with contactless card payments. Hence, the overall effect on cash usage remains unaffected.
\end{abstract}

Keywords: Contactless payment, Money demand, Cash usage, Credit cards, Debit cards

JEL classification: C33, D12, E41, E42

\section{Introduction}

Cash is still the most prominent payment method at the point-of-sale (POS) in numerous developed countries, especially at low transaction values (e.g., von Kalckreuth et al. (2014); Bouhdaoui and Bounie (2012); Arango et al. (2015); Bagnall et al. (2016)). However, the promotion of various technological innovations in retail payment markets such as credit, debit, and prepaid cards has led to a decline in cash usage in recent years (e.g., Lippi and Secchi (2009); Amromin and Chakravorti (2009); Stix (2003)). Recent innovative payment means (e.g., contactless payment) attempt to mimic the desirable features of cash. They promise efficient and convenient payment services that may reduce the transaction costs of payment for consumers. Contactless payment is therefore seen as a more competitive payment alternative to traditional cash payments compared to conventional payment cards. Thus, discussing the prospects of cash usage is high on the agenda of central banks, which are responsible for cash distribution.

Correspondence: tobias.truetsch@unisg.ch

University of St. Gallen, Holzstrasse 15, 9010 St. Gallen, Switzerland
This paper explores the effect of contactless credit and debit cards on cash usage in the early stage of diffusion. The contactless antenna is usually embedded in conventional payment cards such as debit and credit cards. Contactless cards include a chip and a simple wireless sign. The sign is the only distinction to traditional chip cards. Contactless payment is based on near-field communication (NFC) technology. This standard radio communication technology allows paying within a 4-cm range by waving or tapping the payment card. A signature or PIN verification is not necessary below a certain transaction value. Contactless payment therefore offers instantaneous payment, speed, and convenience compared to traditional cards. Polasik et al. (2013) found that contactless payment cards compete with cash payments with respect to speed and under certain conditions even outperform cash. The speed of a transaction is key to determining the choice of payment instruments (e.g., Klee (2006); Jonker (2007)).

Thus, I hypothesize that contactless payment adopters are more likely to exhibit lower cash usage. The effect on the number of cash transactions is expected to be larger compared to cash expenses. This is because contactless
Springer Open

(c) The Author(s). 2020 Open Access This article is licensed under a Creative Commons Attribution 4.0 International License, which permits use, sharing, adaptation, distribution and reproduction in any medium or format, as long as you give appropriate credit to the original author(s) and the source, provide a link to the Creative Commons licence, and indicate if changes were made. The images or other third party material in this article are included in the article's Creative Commons licence, unless indicated otherwise in a credit line to the material. If material is not included in the article's Creative Commons licence and your intended use is not permitted by statutory regulation or exceeds the permitted use, you will need to obtain permission directly from the copyright holder. To view a copy of this licence, visit http://creativecommons.org/licenses/by/4.0/. 
cards-due to their improved speed and convenienceare likely to substitute low cash value payments, which are high in frequency but have low budget impact.

Analyzing the effect of contactless payment on cash usage is relevant for three reasons. First, one of the main responsibilities of central banks is to provide efficient payment services to ensure financial system stability. The number and transaction size of cash payments affect the efficiency of payment systems, as expressed in social welfare costs. van Hove (2008) measured the costs of cash usage in the Netherlands as being $0.48 \%$ of GDP. Schmiedel et al. (2013) estimated the substantial costs of cash, which amount to one half percent of GDP for the EU-27 member states. Thus, understanding the demand for cash is crucial to evaluating the costs of payment systems.

Second, central banks are the sole institutions that are entitled to issue legal tender money. The assessment of future trends in cash demand is a relevant monetary policy issue. More contactless payment cards could imply lower cash in circulation and hence lower seignorage income.

Third, the literature has shown that money demand might react less sensitively to interest rates due to technological improvements in payment processing. This might result in lower welfare costs of inflation (Alvarez and Lippi $(2009))^{1}$.

Three papers have so far examined how contactless payment impacts cash demand. Fujiki and Tanaka (2014) found that average cash balances do not decrease with the adoption of contactless payment and under some specifications even increase. They used household-level survey data from Japan. Fung et al. (2014) showed that contactless credit and stored-value cards reduce average cash usage for transactions in terms of both value and vol$u^{2} e^{2}$. They analyzed consumer-level survey data from Canada. However, both studies failed to purge unobserved heterogeneity due to data restrictions. Chen et al. (2017) used household panel data from Canada to account for endogeneity. They encountered a high attrition rate of about $50 \%$. However, they applied refreshment samples to account for this high attrition rate. They found no statistically significant impact of contactless credit cards on cash usage, neither in terms of value nor of volume after controlling for non-ignorable attrition and unobserved heterogeneity.

This paper contributes to existing literature in three respects. First, it is essential to control for unobserved heterogeneity when examining the effect of contactless

\footnotetext{
${ }^{1}$ Welfare costs of inflation are the amount of less seigniorage revenue due to higher nominal interest rates (real rate plus expected inflation) (Briglevics and Schuh (2013)).

${ }^{2}$ Fung et al. (2014) estimated a decline in cash value due to contactless credit and stored-value cards by roughly -14 and $-12 \%$ and a reduction in cash volume by around -13 and $-15 \%$, respectively.
}

payment on cash usage Chen et al. (2017). I draw on a unique balanced panel dataset from 2009 to 2013. Using such rich datasets represents a novel approach, which does not suffer from non-ignorable attrition. Second, I investigate the effect of contactless debit cards on cash demand and thereby fill an important gap in the literature. This is because debit cards are the most popular cashless payment method. Third, I analyze the impact of contactless payment on cash usage in the USA, one of the biggest payment markets. This is important as there is still missing empirical evidence of contactless payment in the USA payment landscape.

I find evidence that contactless credit and debit cards exert no statistically significant effect on cash usage in the early stage of diffusion. I account for unobserved heterogeneity in cash usage by using the fixed-effects model. Consumers' decision to adopt contactless payment is an endogenous choice. Card-affined individuals replace conventional card payments with contactless card payments. The overall effect on cash usage therefore remains unaffected.

I proceed as follows. Section 2 reviews the relevant literature. Section 3 provides background information on the theoretical framework of the estimation strategy as well as the institutional background of contactless payment in the USA. The data are described in Section 4, followed by empirical specification in Section 5. Section 6 discusses the results while Section 7 draws conclusions and provides a research outlook.

\section{Literature review}

This paper is related to the literature of money demand and the future use of cash with regard to technological improvements. Efforts to estimate precise parameters of the traditional money demand function in light of technological change have produced an important body of literature (e.g., Attanasio et al. (2002); Lippi and Secchi (2009); Alvarez and Lippi (2009); Briglevics and Schuh (2013)).

Some scholars have estimated the share of cash transactions at the POS and its future usage with respect to payment enhancement. The effect of payment innovations on aggregate cash demand is not clear from an empirical point of view. Columba (2009) studied the effect of ATMs and POS terminals on the demand for currency and narrow money M1. He showed that the impact on cash in circulation is negative, whereas it positively affects narrow money.

Others have found that modern payment technologies have little effect on currency usage, mainly due to its superior characteristic of anonymity. Amromin and Chakravorti (2009) showed that demand for low denomination notes and coins decreases as debit card usage increases. This is because merchants need less purse 
money for change. The demand for high denomination notes is less affected because individuals use them for non-transactional purposes such as hoarding and illegal activities. This was highlighted by Drehmann et al. (2004), who pointed out that POS terminals negatively and ATMs positively affect demand for small banknotes. Snellman et al. (2001) argued that debit and credit cards are the main drivers of substituting away from cash, while the effect of ATMs remains ambiguous (cf. Humphrey (2004)).

Another strand of the literature has employed household survey data to more precisely study cash usage. Stix (2003) found that debit cards negatively affect demand for purse cash in Austria. von Kalckreuth et al. (2009) argued that credit cards have no impact on the number of cash transactions in Germany. However, Huynh et al. (2014) reported that merchants' acceptance of payment cards has a substantial negative impact on the demand for cash in Austria and Canada.

\section{Background information}

\subsection{Theoretical background}

I derive the theoretical background for the estimation strategy and the empirical methodology used here from McCallum and Goodfriend (1987) framework. Attanasio et al. (2002) presented this framework as an extension of the traditional Baumol-Tobin model (Baumol (1952); Tobin (1956)). The extended model takes into account innovations in transaction technologies. Accordingly, individuals adopt payment innovations if the benefits of adopting the technology exceed the costs. Adoption costs of contactless payment may include (one-time) operational learning costs, monetary costs of using and adopting the payment card (e.g., annual fees, surcharges), and the availability of contactless terminals.

Benefits of payment innovations increase with improving transaction efficiency. This makes adopting contactless payment more likely since it allows for a fast payment process. Polasik et al. (2013) showed that contactless payment cards are the first payment method to be faster than cash. The transaction speed is one of the most important factors to determine the choice of a payment instrument (e.g., Klee (2006); Jonker (2007)). This is because it reduces queue lines and thus consumers' payment costs (Brits andWinder (2005)). Younger consumers in particular react more negatively to longer payment processing than older consumers and are therefore more likely to adopt contactless payment (Borzekowski and Kiser (2008)).

Benefits also tend to rise with more consumption expenditures and higher transaction values because more spending is subject to longer transaction times. Consequently, the rate of adopting contactless payment varies by consumers' demographic characteristics (e.g. income, age, education), which determine their opportunity costs of paying. High-income individuals are therefore more likely to adopt contactless payment to reduce their transaction costs of paying. This is because their opportunity costs of paying tend to be higher than for low-income individuals. For the same reason, cash demand tends to be lower for contactless adopters than non-adopters because cash payments take more time to settle than contactless payments (cf. Polasik et al. (2013)).

In general, individuals need time to undertake transactions. As a form of exchange and financial innovations, money reduces the transaction time (Attanasio et al. (2002)). In the traditional Baumol-Tobin setting, individuals face a trade-off between holding liquidity in form of money, in order to carry out transactions, and the forgone interest paid on deposited assets. However, in Attanasio et al. (2002) extended version of the model, consumers choose optimal money holdings to trade off transaction costs against the costs of holding cash. Transaction time costs originate from the shadow value of time and from the "shoe-leather" costs of withdrawing cash.

Hence, consumers demand optimal money holdings by minimizing both the transaction time costs and the forgone interest paid on deposited assets subject to their consumption expenditures. Improvements in transaction technology (e.g., contactless payment) and lower transaction costs therefore lessen the demand for cash. Contactless payment also enables instantly accessing liquid assets in accounts for making payments. This further reduces the demand for cash and maximizes the return of interest paid on deposited assets. Thus, higher interest rates on deposited accounts create more incentives to park money holdings that in turn reduce the demand for cash. Conversely, higher consumption expenditures increase the demand for cash.

\subsection{Institutional background}

Contactless payment was first launched in the USA in 2005 by only very few issuing banks. The survey data used in this study show that the rate of contactless card adoption for credit and debit cards remained relatively stable (at around 10\%) between 2009 and 2013 (see Fig. 1). The low adoption rate approximately agrees with actual data about contactless card adoption provided by the Federal Reserve System for the year 2012 (see Table 1). The actual rate of contactless credit cards was $7 \%$, that of debit cards $8 \%$.

At the time, adopting contactless payment was an endogenous decision in the USA. Only a few banks reissued contactless cards by default when traditional payment cards expired. Some issuers provided contactless cards only upon request or exclusively to new customers. These were not required to pay extra for the contactless feature (cf. Chai (2017)).

Compared to other countries like Canada or Australia, the adoption of contactless cards in the USA in the 20092013 period failed to take off for various reasons. First, the 


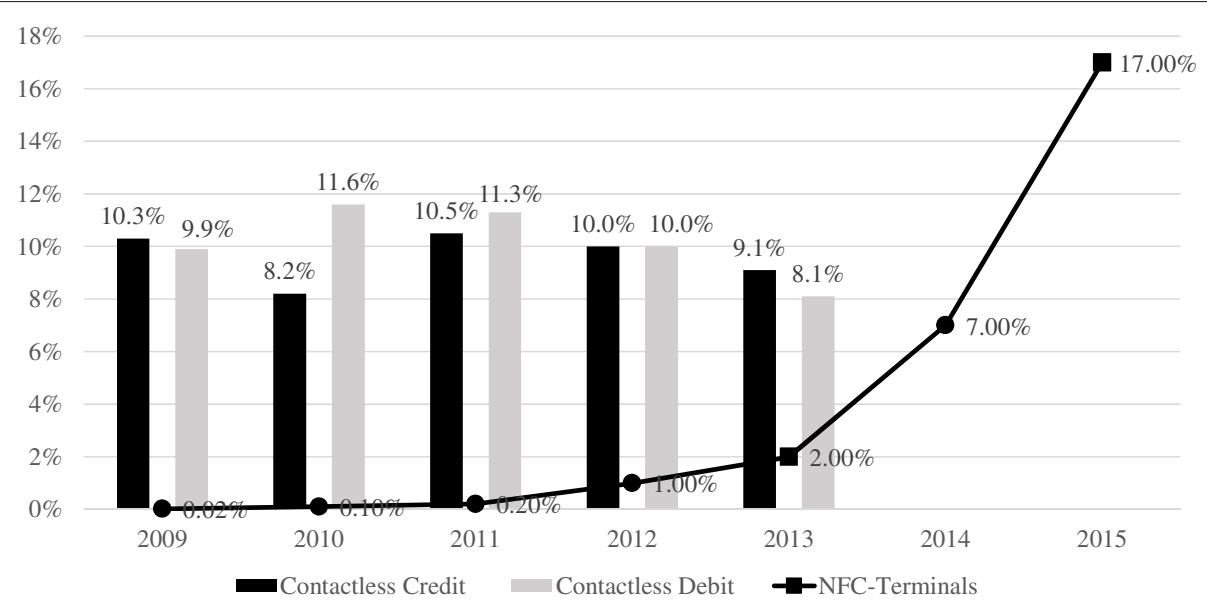

Fig. 1 The evolution of contactless cards and NFC terminals. Note: The shares refer to the contactless data related to their corresponding total data. For instance, $9.1 \%$ of all credit cards and 2\% of all POS terminals were contactless in 2013 in the USA. The Surveys of Consumer Payment Choice (SCPC) provide the share of contactless cards. They no longer included any information on contactless payment after 2013. The share of contactless terminals for the year 2015 is derived from LTP (2015), for the year 2013 from SPA (2016). The remaining fractions are computed according to the logistic regression analysis. Other data points are not available

US banking and merchants sectors were very fragmented. Both sectors pursued different contactless payment strategies (SPA (2016)). Second, banks were legally obliged to shift completely to EMV (Europay International, MasterCard and VISA) standard payment cards by 2015. These types of cards enable storing data on chips rather than on magnetic stripes. Banks incurred significant manufacturing costs to overhaul these card portfolios given the immense US market for payment cards. Therefore, most banks decided to issue single-interface chip cards with no contactless antenna for saving money ${ }^{3}$. Third, and as a consequence, US retailers had never been eager to install contactless-enabled POS terminals due to lack of contactless card adopters. As a result of missing acceptance, individuals' contactless payment adoption lagged behind and further led banks to slow down issuing contactless payment cards (SPA (2016)).

Figure 1 shows the very low level of contactless card acceptance at the POS during the years 2009-2013, ranging from roughly 0.02 to $2 \%$. This goes hand in hand with actual usage of contactless cards (see Table 1): Only around $0.1 \%$ of all credit and debit card payments in the USA were made contactless in 2009 and 2012. Such payments accounted for approximately $0.1 \%$ of total transaction value. In other words, an average of less than one payment per card was made using contactless technology in 2012 (see Table 1). This made contactless payment a rare novelty in terms of usage.

\footnotetext{
${ }^{3}$ Canada, for instance, skipped first generation single-interface (EMV) chip cards and deployed contactless cards from the outset.
}

\section{Data}

\subsection{Source}

Data are drawn from the Federal Reserve Bank of Boston, which has conducted the Survey of Consumer Payment Choice (SCPC) since 2008. The surveys are performed in autumn (fourth quarter)-primarily in October-by the RAND Corporation as unique, comprehensive, and representative online surveys using RAND's American Life Panel (ALP). They provide detailed payment information about individuals with respect to nine payment instruments (including cash) used in the USA ${ }^{4}$.

The ALP's sampling unit is an individual US consumer older than 18 years, whose responses to each survey are weighted to represent all US consumers aged 18 years and older. The 2008 responses are not comparable due to major revisions in the questionnaire and methodology across years. The survey series aims to provide a consumer-level longitudinal dataset and forms a valuable longitudinal balanced panel from 2009-2013 with respect to payment choice. The surveys conducted after 2013 no longer include information about contactless payment. One thousand one hundred thirty-two respondents completed all five surveys, which included similar and identical questions (see Table 2$)^{5}$.

Table 2 depicts the number of respondents per survey and the various panelists. It shows an annual rate of attrition of roughly $10 \%$ until 2012, whereas this increased to

\footnotetext{
${ }^{4}$ These include cash, checks, money orders, traveler's checks, debit, credit, and prepaid cards, online banking bill payments, and bank account number payments.

${ }^{5}$ I refer to Foster et al. (2013); Schuh and Stavins (2014) and Schuh and Stavins (2015) for a comprehensive description of each dataset, a synopsis of the results and detailed information about the collection process.
} 
Table 1 Actual adoption and usage of contactless payment cards in the USA

\begin{tabular}{|c|c|c|c|c|}
\hline & 2009 & in \% & 2012 & in $\%$ \\
\hline \multicolumn{5}{|l|}{ Credit cards } \\
\hline Number of contactless cards (m) & $\mathrm{n} / \mathrm{a}$ & & 23.35 & $7.0 \%$ \\
\hline Contactless transaction volume (m) & 20 & $0.10 \%$ & 13 & $0.07 \%$ \\
\hline Contactless transaction value (m) & 1000 & $0.06 \%$ & 600 & $\mathrm{n} / \mathrm{a}$ \\
\hline \multicolumn{5}{|l|}{ Debit cards } \\
\hline Number of contactless cards (m) & $\mathrm{n} / \mathrm{a}$ & & 22.62 & $8.0 \%$ \\
\hline Contactless transaction volume (m) & 30 & $0.15 \%$ & 27 & $0.07 \%$ \\
\hline Contactless transaction value (m) & 1000 & $0.08 \%$ & 378 & $\mathrm{n} / \mathrm{a}$ \\
\hline \multicolumn{5}{|c|}{ Average number of contactless transactions per } \\
\hline Credit card & $\mathrm{n} / \mathrm{a}$ & & 0.57 & \\
\hline Debit card & $n / a$ & & 1.19 & \\
\hline
\end{tabular}

Source: Federal Reserve System (cf. FED (2011; 2014). Newer data are not available. Contactless payments are labeled "chip" card payments in the report provided by the Federal Reserve in 2014. "m" is millions. The shares refer to the contactless data related to their corresponding total data. For instance, $0.1 \%$ of all credit card transactions in 2009 were made contactless. In other words, contactless credit card transaction volume is divided by the total credit card transaction volume

around 35\% in 2013. This is because the SCPC incorporated the novel payment diary in 2012, thus more strongly emphasizing demographic coverage (cf. Angrisani et al. $(2015))^{6}$. The retention rate between 2009 and 2012 was around $70 \%$ (1515 individuals). Around 90\% of respondents who once participated in the SCPC before 2013 also participated in 2013 (Angrisani et al. (2015)). Among the 2169 individuals observed in 2009, 52\% (1132) participated throughout (i.e., 2009-2013).

Tables 10 and 11 (see Appendix) provide first-year summary statistics of stayers participating for five consecutive years versus attritors, in order to check whether panel attrition is systematic. The statistics reveal that attrition is likely to be random, i.e. exhibiting no systematic pattern ${ }^{7}$.

The SCPC asks consumers what payment instruments they have and how often they use these instruments. The survey employs a flexible reporting strategy to enhance recall and to optimize the accuracy of the number of payments ${ }^{8}$. It also collects comprehensive data on consumer cash holdings and cash withdrawal behavior. Low-value payments tend to be more easily forgotten due to their high frequency and low budget impact. They are mostly effected in cash, which may lead to underreporting. Thus, cleaning procedures were applied to identify and edit invalid data entries for the number of monthly payments of all payment instruments and the typical value of cash withdrawals. The dataset also provides rich information

\footnotetext{
${ }^{6}$ The 2012 SCPC included an additional 1111 new respondents to the 2065 respondents with previous experience due to the novel payment diary. Many of the new respondents came from demographic strata poorly represented in the pool of respondents with previous SCPC experience (Angrisani et al. (2015.))

${ }^{7}$ Statistically, attritors significantly differ with respect to three variables (among the 45 characteristics): They are more likely to earn between 100,000 and 124,000 USD, to be retired and to withdraw cash more frequently. However, overall differences are suggested to be unsystematic.

${ }^{8}$ Typical periods that measure the number of payments are during a week, a month, or a year. They are quite consistent with the implicit average that represents consumers' trend behavior (Schuh and Stavins (2015.))
}

about consumer demographic characteristics, financial status, and the rating of payment instrument attributes.

However, there are several limitations. The 2009-2013 estimates are not consistently adjusted for seasonal variation, inflation, or item non-response (missing values). The calendar time period of the 2009 survey also differs slightly from that of the 2010-2013 surveys. The latest surveys are very similar in terms of size, composition and timing of the sample. Survey comparability across years may suffer from different survey timing if crucial monthly seasonal differences occurred in individual payment behavior. Also, consumers may have underreported the number of payments and withdrawals in the years 2009-2010 (i.e., during the financial crisis and the corresponding severe recession). The rationale is that consumers generally relied more on cash payments in those days. These may be harder to recall due to their high frequency and low budget impact. Additionally, no longitudinal sample weights are available.

\subsection{Description}

This section describes the 2009-2013 panel dataset used here for estimation. The surveys specifically ask respondents if one of their credit and debit cards is equipped

Table 2 Panel data structure

\begin{tabular}{llllll}
\hline & $\mathbf{2 0 0 9}$ & $\mathbf{2 0 1 0}$ & $\mathbf{2 0 1 1}$ & $\mathbf{2 0 1 2}$ & $\mathbf{2 0 1 3}$ \\
\hline Nr. of respondents & 2173 & 2102 & 2151 & 2065 & 2089 \\
2009-2010 panelists & 1913 & 1913 & & & \\
2010-2011 panelists & & 1801 & 1801 & & \\
2011-2012 panelists & & & 1926 & 1926 & \\
2012-2013 panelists & & & & 1330 & 1330 \\
2009-2012 panelists & 1515 & 1515 & 1515 & 1515 & \\
2009-2013 panelists & 1132 & 1132 & 1132 & 1132 & 1132 \\
\hline
\end{tabular}

Source: Schuh and Stavins (2014) and Angrisani et al. (2015) 
Table 3 Adoption and usage rate of payment cards in the 2009-2013 surveys

\begin{tabular}{llll}
\hline Variable & Mean & SD & Obs \\
\hline Contactless credit cards & 0.095 & 0.294 & 5659 \\
Contactless debit cards & 0.103 & 0.304 & 5657 \\
Credit cards & 0.759 & 0.428 & 5628 \\
Debit cards & 0.78 & 0.414 & 5620 \\
Credit card usage & 0.613 & 0.487 & 5625 \\
Debit card usage & 0.63 & 0.483 & 5619 \\
\hline
\end{tabular}

Usage describes the fact that respondents make the corresponding type of payment at least once in a typical month. Survey weights used

with the contactless feature. This estimate is likely to be fairly robust since the decision to adopt contactless payment is endogenous. Some consumers actively applied for contactless cards. Unfortunately, the surveys provide no information on the specific usage patterns of contactless payment. Contactless adopters are labeled as innovators, or as non-innovators, irrespective of having any payment cards. Non-innovators are a relatively homogenous group of payment card adopters. Roughly $76 \%$ of respondents owned a conventional credit card and $78 \%$ a debit card within the observed period (see Table 3$)^{9}$. Credit and debit cards were used at least once a month by around 61 and $63 \%$ of all respondents between 2009 and 2013.

Around $10 \%$ of consumers in the overall period reported that one of their credit cards had the embedded contactless feature (see Table 3). Approximately 10\% stated that they possess a contactless debit card.

The surveys also collect data on consumer cash withdrawal behavior. Consumers were asked about the amount of cash they most often withdraw and the number of withdrawals they usually make in a typical period (week, month, or year). Both questions were asked for two separate withdrawal locations: the primary one, where consumers most often obtain cash, and all other sources ${ }^{10}$. Like Briglevics and Schuh (2013); this study focuses on the figures for the primary location. These estimates tend to be more precise. Reporting the usual rather than the actual withdrawal amount reduces the mental burden to compute averages of potentially diverse cash withdrawals (cf. Briglevics and Schuh (2013)). The SCPC also states the number of cash payments and the total number of all purchases made in a typical month at the POS. Its ratio measures the cash share in terms of volume. This is a robust measure towards outliers.

Table 4 describes the summary statistics of the main cash measure variables in the panel dataset. The average

\footnotetext{
${ }^{9}$ These numbers are higher in the estimation sample since only checking account holders is considered. Additionally, more than half of total payments in the survey were made by payment cards.

${ }^{10}$ Cash withdrawal locations include ATMs, bank tellers, check cashing stores, cash back at retail stores, family or friends and others as well as being paid in cash.
}

Table 4 Summary statistics of cash measures

\begin{tabular}{lllll}
\hline Statistics & $\begin{array}{l}\text { Usual } \\
\text { withdrawal }\end{array}$ & $\begin{array}{l}\text { Nr. of } \\
\text { withdrawals }\end{array}$ & $\begin{array}{l}\text { Cash } \\
\text { in wallet }\end{array}$ & $\begin{array}{l}\text { Cash share } \\
\text { in volume }\end{array}$ \\
\hline Mean & 128.845 & 3.716 & 72.586 & 0.355 \\
SD & 172.734 & 6.610 & 134.691 & 0.285 \\
Median & 80.000 & 2.000 & 40.000 & 0.312 \\
Min. & 0.000 & 0.000 & 0.000 & 0.000 \\
P-10\% & 20.000 & 0.833 & 1.000 & 0.000 \\
P-99\% & 850.000 & 26.089 & 500.000 & 1.000 \\
Max. & 5000.000 & 434.821 & 3500.000 & 1.000 \\
Obs. & 5561 & 5572 & 5577 & 5527 \\
\hline
\end{tabular}

Cash management measures are reported in USD except the number of withdrawals and cash share. The usual cash withdrawal amount and the number of withdrawals relate to the primary location. Cash share is the ratio of the total number of cash transactions in a typical month at the POS to the total number of all purchases in a typical month at the POS. Survey weights used

amount of cash in wallet (73 USD) is roughly half of the average usual withdrawal amount (130 USD). The average number of withdrawals at the primary location per month amounts to around 4 . Roughly $36 \%$ of all POS payments are made in cash (cash share in volume). Half of the consumers reported a cash ratio both lower and higher than $28.5 \%$. Median values of the remaining cash measures were roughly half of the average values. This indicates that a small number of respondents relied heavily on cash, resulting in high standard errors. The maximum values of the cash variables support this finding (see Table 4).

For this reason, I winsorize the usual cash amount withdrawn, the number of withdrawals and the average cash value in wallet at the $99 \%$ level. This enables properly analyzing the mean difference between innovators and non-innovators. Tables 5 and 6 report (winsorized) statistics of the relevant cash measures distinguished by contactless credit and debit card innovators and noninnovators. I also provide univariate mean comparison tests and Wilcoxon rank-sum tests between innovators and non-innovators in order to detect statistically significant differences ${ }^{11}$.

Table 5 shows that statistically contactless credit card adopters significantly make fewer cash withdrawals within a month than non-adopters (roughly 2.9 vs. 3.5 ). Another notable statistical difference is that adopters also have a 9 percentage point lower cash ratio in volume than nonadopters. Further, while their usual withdrawal amount tends to be smaller than that of non-innovators (around 8 USD), they carry slightly more cash in wallet (+1 USD). The Wilcoxon rank-sum test supports these results.

Statistically, contactless debit card innovators make significantly more cash withdrawals $(+0.8)$ compared to non-innovators (see Table 6). However, they withdraw

\footnotetext{
${ }^{11}$ The Wilcoxon rank-sum test tests if the samples of innovators and non-innovators come from populations with the same distribution.
} 


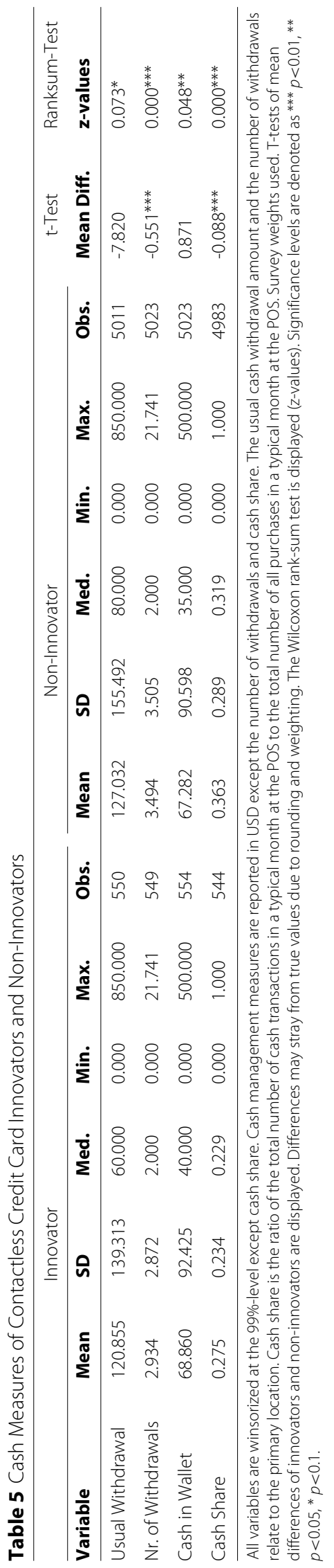




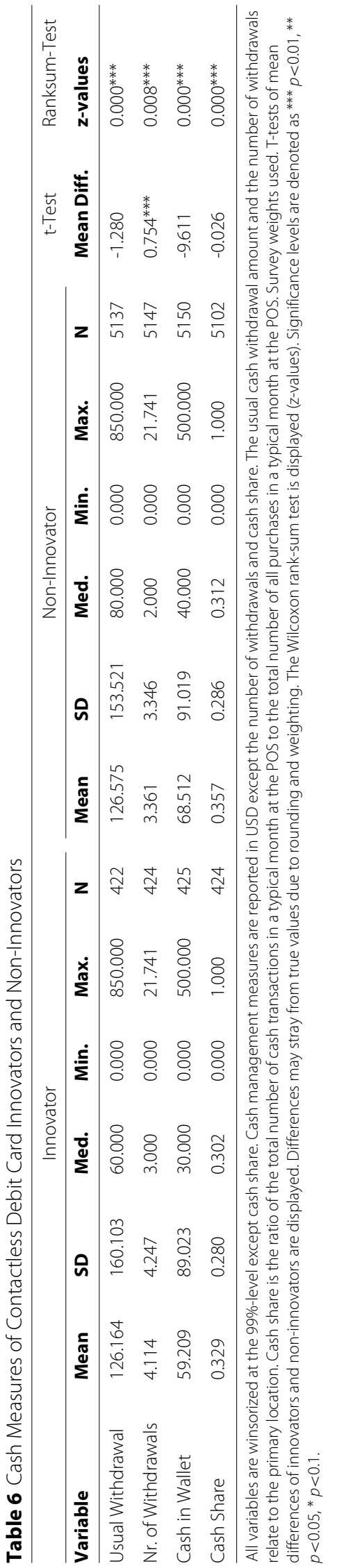


Table 7 Adoption patterns of contactless payment in the entire sample

\begin{tabular}{|c|c|c|c|c|c|c|}
\hline \multirow{2}{*}{ Contactless credit cards for $\mathrm{t} ; \mathrm{T}$} & \multicolumn{6}{|c|}{ Contactless debit cards for t;T } \\
\hline & $\mathrm{N}-\mathrm{I} ; \mathrm{N}-\mathrm{I}$ & $\mathrm{N}-\mathrm{I} ; \mathrm{I}$ & I; N-I & $1 ; 1$ & Multiple switcher & Total \\
\hline Non-innovator; non-innovator & 56.81 & 3.03 & 2.03 & 0.62 & 9.62 & 72.11 \\
\hline Non-innovator; innovator & 2.83 & 0.94 & 0.22 & 0 & 1.86 & 5.85 \\
\hline Innovator; non-innovator & 3.21 & 0 & 1.59 & 0 & 1.24 & 6.04 \\
\hline Innovator; innovator & 0.34 & 0.24 & 0 & 0 & 0.37 & 0.95 \\
\hline Multiple switcher & 7.71 & 1.05 & 0.58 & 0.1 & 5.6 & 15.04 \\
\hline Total & 70.92 & 5.26 & 4.42 & 0.72 & 18.69 & 100 \\
\hline
\end{tabular}

Numbers are in proportions and correspond to the 2009-2013 year balanced panel. Survey weights used. N-I and / denote non-innovators and innovators, respectively. Missings are coded according to the value of their previous year. $t=2009,2010,2011,2012,2013$

lower cash amounts ( -1.3 USD), have a lower average cash amount in wallet ( -9.6 USD) and a lower average cash ratio in volume $(-3 \%)$ than non-innovators. The Wilcoxon rank-sum test indicates that statistically the medians of contactless debit card innovators and noninnovators differ significantly.

To sum up, descriptive evidence shows that contactless payment may reduce both the volume and the value of cash transactions, whereas the latter primarily holds for contactless credit cards.

Five different types of contactless payment adopters can be defined based on the transition patterns of contactless payment in all five consecutive years in the entire 20092013 balanced panel:

1. Never-innovators (non-innovator; non-innovator);

2. Stayers (start-adopters and one-time switchers), who start without contactless payment, eventually adopt it within the five-year period and hold it to the end (non-innovator; innovator);

3. Leavers (stop-adopters and one-time switchers), who start with contactless payment and eventually dismiss it within the 5-year period (innovator; non-innovator);

4. Permanent innovators (innovator; innovator);

5. Multiple switchers (the rest), who switch between adoption and non-adoption of contactless payment one or several times within the 5-year period.

Table 7 provides adoption patterns of contactless payment for these five types of adopters in the years 20092013. It does so separately for contactless credit and debit cards. The matrix both displays the total share of each adoption type and all their possible combinations. This enables revealing the proportions of consumers who, for instance, simultaneously have contactless debit and credit cards.

Overall, penetration rates of contactless credit and debit cards are very similar. The presence of contactless payment is quite modest in the sample. Around 72 and $71 \%$ of respondents never adopted contactless credit or debit cards (non-innovator; non-innovator). Roughly $1 \%$ of consumers are permanent innovators of both payment cards, around 6\% (credit) and 5\% (debit) are stayers (non-innovator; innovator), roughly 6\% (credit) and $4.5 \%$ (debit) are leavers (innovator; non-innovator), and approximately $15 \%$ (credit) and 19\% (debit) are multiple switchers ${ }^{12}$.

Table 7 also provides information about multiple payment innovation adopters. Around $57 \%$ of respondents never adopted any contactless payment card in the entire period. $41.5 \%$ of consumers who adopted contactless credit cards at some point also adopted contactless debit cards within the years 2009-2013. 47.5\% of one-time contactless debit card adopters had contactless credit cards at some point ${ }^{13}$. Furthermore, around $43 \%$ of all consumers in the sample had one of the two innovations at some stage, but only around $14 \%$ possessed both innovations at the same time ${ }^{14}$.

Stayers exhibited lower cash shares in volume in every year from 2009-2013 compared to never-innovators (see

\footnotetext{
${ }^{12}$ The relatively sizable number of multiple switchers could rely on the fact that US consumers possess on average 6.5 debit and credit cards issued by different banks.

${ }^{13}$ The proportions are calculated using the sum of debit card innovators among credit card innovators (11.56\%) in relation to the sum of credit card innovators (27.89\%) and vice versa (13.79 vs. $29.02 \%)$.

${ }^{14}$ Table 7 does not provide this information.
} 


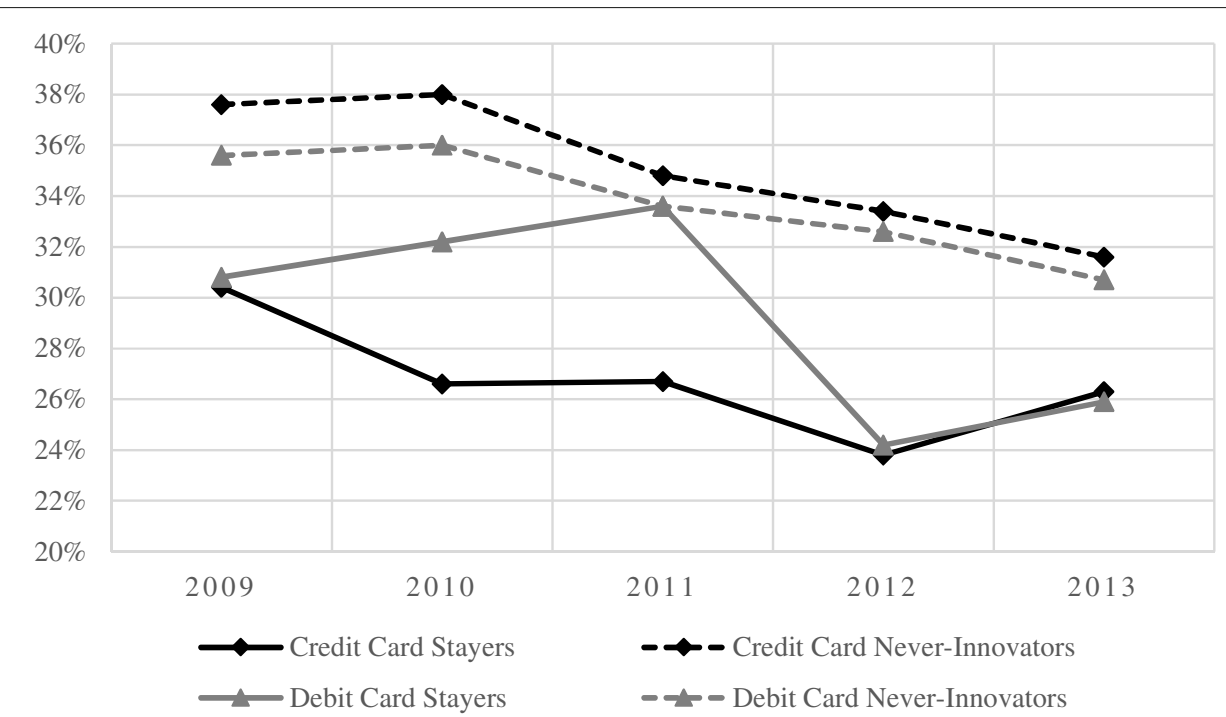

Fig. 2 The Evolution of the cash share volume between never-Innovators and stayers. Cash share volume is the ratio of the number of cash payments to the total number of all purchases made in a typical month at the POS

Fig. 2) ${ }^{15}$. Cash shares also decreased over the years. This indicates that contactless payment adopters may have already used less cash before adopting contactless payment compared to never-adopters.

The dataset additionally provides rich information on demographic and financial characteristics. Table 12 (see Appendix) tabulates these statistics separately for contactless credit and debit card holders. It also includes the results of the mean comparison tests. The sample of contactless credit card adopters is statistically significantly more skewed towards higher income and education brackets (see Table 12). Credit card innovators are more frequently employed, widowed, between 55 and 64 years old, Asian, revolvers, and home owners. However, they are less likely to be single and black compared to noninnovators. These mean differences are all statistically significant.

As opposed to credit card innovators, statistically, the sample of contactless debit card adopters is significantly more skewed towards lower-income and lower-education brackets (see Appendix, Table 12). They are mostly younger, working, Black, Asian, Latino, or of another ethnicity, and are less likely to own a home and be retired compared to non-innovators.

To conclude, the descriptive statistics have offered some suggestive evidence that contactless payment is related to reduced cash usage in terms of value and volume. They have also revealed that assignment to the contactless feature is likely to be non-random.

\footnotetext{
${ }^{15}$ The differences are not statistically significant. Similarly, cash measures in value overall tend to be smaller for stayers than for never-innovators.
}

\section{Methodology}

The panel dimension of the SCPC was used to estimate the relationship between contactless payment and cash demand. The standard panel data model with unobserved heterogeneity $\eta_{i}$ is

$$
M_{i t}=\alpha I_{i j t}+\beta X_{i t}+\gamma Y_{i t}+\delta R_{i t}+\epsilon_{i t}+\eta_{i},
$$

where $M_{i t}$ denotes the measurement of cash usage, $I_{i j t}$ takes the value of one if the individual is an innovator, i.e., a contactless payment adopter for payment method $j$, where $j$ relates to debit and credit cards, respectively. $X_{i t}$ are the observed individual characteristics and a vector of proxies for transaction costs, as evidenced by Connolly and Stavins (2015). $Y_{i t}$ is the household income to proxy for consumption expenditures ${ }^{16}, R_{i t}$ is the interest rate for primary checking accounts and the alternative cost of holding cash, and $\epsilon_{i t}$ is the error term for all $i . \alpha$ is the parameter of interest, which measures the effect of contactless payment on cash usage.

The variable $I_{i j t}$ must be strictly exogenous to obtain an unbiased estimate of the parameter $\alpha$. However, the descriptive analysis has shown that adopting contactless payment is likely to be a non-random decision. Some unobserved variables may cause individuals to select into innovation $I_{i j t}$ and simultaneously use less cash (cf. Fung et al. (2014)). For instance, individuals with an affinity for new technologies may be more prone to hold less cash and be more likely to use contactless payment. Thus, the estimate may be biased and inconsistent (selection bias). Omitted variables related to payment automatism may also confound the estimation results (omitted

\footnotetext{
${ }^{16}$ See Appendix for the variable definition.
} 
variable bias). Payment behavior has been found to be largely habitual (van der Horst and Matthijsen (2013)). Unobserved individual-specific fixed-effects $\eta_{i}$ may thus correlate with the explanatory variable $I_{i j t}$, which introduces a bias into the estimation ${ }^{17}$.

Furthermore, contactless payment and cash usage may suffer from reverse causality (cf. Fung et al. (2014)). Individuals who rely less on cash may adopt contactless payment to meet their personal preferences for frequent usage of payment cards, as this permits instantaneous payment. It is thus not evident if innovation drives cash demand or vice versa (simultaneity bias). The estimation includes perceived characteristics of cash relative to payment cards $\left(\right.$ RCHAR $\left._{k i t}\right)$ in order to address this issue. However, appropriate instrumental variables would be more fruitful.

This study uses the within-group estimator (meandifference model) to reduce concerns about unobserved individual fixed-effects by exploiting the panel dimension of the data to yield ${ }^{18}$

$$
\begin{aligned}
\left(M_{i t}-\bar{M}_{i}\right) & =\alpha\left(I_{i j t}-\bar{I}_{i j}\right)+\beta\left(X_{i t}-\bar{X}_{i}\right)+\gamma\left(Y_{i t}-\bar{Y}_{i}\right) \\
& +\delta\left(R_{i t}-\bar{R}_{i}\right)+\left(\epsilon_{i t}-\bar{\epsilon}_{i}\right) .
\end{aligned}
$$

The usual withdrawal amount, the cash kept in wallet, and the number of withdrawals in a typical monthwinsorized at the $99 \%$ level-represent the variable $M_{i t}$ as the parameter for transactional cash demand. These variables analyze the effect on cash value (cf. Briglevics and Schuh (2013) $)^{19} . M_{i t}$ also serves as the variable for cash share in volume.

Equation 2 represents the baseline specification to be estimated. As an additional set of controls, I included the perceived characteristics $k=$ security, setup, acceptance, costs, records, and convenience of cash $\left(R C H A R_{\text {kit }}\right)$ into

\footnotetext{
${ }^{17}$ Payment markets inherently include the two-sided market structure, where network effects are predominant. The value of contactless payment for a consumer depends on the number of others using this instrument. If the critical level of users is not exceeded, merchants would not invest in contactless payment terminals due to small economies of scale. Hence, the adoption and usage of contactless payment may face feedback effects. Consumers therefore choose contactless payment contingent upon the number of available contactless terminals.

${ }^{18}$ If individual effects are random and uncorrelated with the variable $I_{i j t}$, it leads to the random-effects model. However, employing the Hausman test on the balanced panel for all specifications rejects the null hypothesis of the random-effects model (test statistics are not provided). Therefore, the random-effects model does not provide consistent estimates compared to the fixed-effects model.

${ }^{19}$ Money holdings $M$ conceptually represent cash for transactional purposes in the classical model of cash demand. Individuals, however, do not only hold money for spending purposes but also for hoarding and precautionary reasons. Large cash holdings may also be motivated by anticipating large purchases and could be related not only to retail payments but also to in-person payments beyond POS payments. In this study, the measures of actual cash holdings may thus differ from balances consumers held for actual cash transactions. It is unfeasible to accurately measure cash demand without accurate transactional-level data. However, the reported amount of cash usually withdrawn, the cash kept in wallet, and the number of withdrawals are closely related to transactional cash balances (cf. Briglevics and Schuh (2013)).
}

the second specification ${ }^{20}$. This is because a significant amount of unobserved heterogeneity in cash usage can be captured by including individuals' perceptions on payment methods characteristics (Jonker (2007); Kim et al. (2006); Ching and Hayashi (2010)). The third specification controls for individuals' primary cash withdrawal method $W M_{i t}$ as a proxy for the "shoe-leather"costs of withdrawing cash (cf. Briglevics and Schuh (2013)) ${ }^{21}$.

I assume that consumers must have an interestbearing bank account to be eligible for payment cards. Therefore, I use the subsample of checking account holders $^{22}$. This has the advantage of eliminating the self-selection bias into payment cards since individuals are likely to open bank accounts to reduce transaction costs. Also, I limit the analysis to the subsample of neverinnovators and stayers in order to distinctly appraise the effect of contactless payment on cash demand (see Table 7).

\section{Estimation results}

This section presents the estimation results of the model specification in Eq. 2 using fixed-effects (FE). Additionally, it reports the results of the cross-sectional analysis (OLS) using the dataset in 2013 (see Appendix). Tables 13, 15, 17 , and 19 show the full set of OLS estimates for contactless credit cards. Tables 14, 16, 18, and 20 exhibit the full set of OLS estimates for contactless debit cards. Fixed-effects and OLS estimates are compared to comprehend the importance of controlling for unobserved heterogeneity.

Overall, the study reveals two major findings: first, individual-specific fixed-effects are present and contactless payment adopters positively selected. This is because FE estimates of contactless payment are mostly smaller than OLS estimates. The large differences in the goodness-of-fit $\left(R^{2}\right)$ between the OLS and the FE models also indicate that cash usage differs more between individuals than over time (within). Second, contactless payment exerts no impact on individual cash payment behavior in the early stage of diffusion. Individuals with an affinity for payment cards are likely to replace traditional card payments in favor of contactless payments. In this way, the effect of contactless payment on cash usage is unaffected.

Below, I first discuss the effect of contactless credit cards on cash usage before analyzing the impact of contactless debit cards on cash demand.

\footnotetext{
${ }^{20}$ See Appendix for variable definition.

${ }^{21}$ Cash withdrawal methods include ATM (49\%), bank teller (23\%), check casher $(2 \%)$, cashback (13\%), employer $(4 \%)$, family $(6 \%)$, and others $(3 \%)$. The figures in brackets show the share of respondents using the specific withdrawa method. Innovators statistically significantly withdraw cash more frequently from ATMs and less often from check cashers than non-innovators.

${ }^{22}$ Approximately $97 \%$ of individuals in the sample have a checking account.
} 


\subsection{Effects of contactless credit cards}

I estimate three specifications using different controls for four types of cash measures. Table 8 presents the main results of the impact of contactless credit cards on cash usage. The results of the full set of covariates for each regression are reported in the Appendix ${ }^{23}$.

I find evidence that contactless credit cards have no statistically significant effect on cash expenses and cash share volumes in all specifications. The results are rather robust against the inclusion of additional controls. The estimated coefficients of contactless credit cards regarding the cash share volume and the number of withdrawals display the expected negative signs. However, the point estimates on the cash in wallet and usual cash withdrawn exhibit, against expectation, a positive sign in all regressions.

The estimates of the cross-sectional analysis show that statistically contactless credit cards significantly reduce cash share volume by approximately 5 to $6 \%$, holding everthing else constant. This is around half the size estimated by Fung et al. (2014) and comparable to Chen et al. (2017), who used cross-sectional and pooled data, respectively $^{24}$. Unobserved heterogeneity therefore drives the results using cross-sectional data.

\subsection{Effects of contactless debit cards}

Table 9 displays the main estimates of the regressions that analyze the impact of contactless debit cards on cash usage. The full set of estimates is provided in the Appendix ${ }^{25}$.

Statistically, contactless debit cards significantly influence the number of withdrawals (see column [1]). The coefficient of the contactless feature has the predicted negative sign, but is sensitive to the inclusion of additional control variables. The estimated negative impact has a modest magnitude of -0.9 , holding everything else constant. In other words, contactless debit cards induce individuals to make 0.9 fewer cash withdrawals per month. This is a sizeable reduction of $28 \%$ compared to the average number of withdrawals per month of 3.2. However, this effect becomes statistically irrelevant using additional control variables. It thus proves to be non-robust.

The impact of contactless debit cards on the remaining cash measure variables is statistically insignificant. Contrary to expectation, the estimated coefficients in column (3) show a positive relationship with cash share volume and cash in wallet. The point estimate in the usual cash

\footnotetext{
${ }^{23}$ The number of observations decreases in the estimations using control sets one and two because withdrawal methods and some perceived characteristics were not surveyed in 2009.

${ }^{24}$ Fung et al. (2014) and Chen et al. (2017) estimated a negative effect of contactless credit cards on the cash share volume at roughly 13 and $8 \%$ using cross-sectional and pooled data, respectively.

${ }^{25}$ The number of observations decreases in the estimations using control sets one and two because withdrawal methods and some perceived characteristics were not surveyed in 2009.
}

withdrawal regression has the expected negative sign. In sum, contactless debit cards exert no impact on individual cash payment behavior.

In the cross-sectional estimation, contactless debit cards are associated with a statistically significant decline in cash share volume by approximately 4 to $6 \%$, holding everything else constant. The results are rather insensitive to the inclusion of additional control variables and comparable to the effect of contactless credit cards. Conversely, contactless debit cards have no statistically significant effect on cash in value.

Overall, the findings demonstrate that consumers selfselect into contactless payment. This leads to spurious results if unobserved heterogeneity is ignored (cf. Chen et al. (2017)).

\section{Conclusion}

This paper has investigated the impact of contactless payment on cash usage in the early stage of diffusion. Multiple layers of endogeneity are likely to be present in this setting, which requires an appropriate estimation strategy to obtain unbiased and consistent estimates. I have therefore employed the within estimator using a unique balanced panel dataset from 2009-2013 in the USA. This has allowed eliminating individual-specific fixed-effects.

I have found evidence that contactless credit and debit cards exert no statistically significant effect on cash usage in the early stage of diffusion after controlling for unobserved heterogeneity in cash usage. Consumers nonrandomly choose contactless payment cards. Card-affined individuals replace conventional card payments with contactless card payments. The overall effect on cash usage therefore remains unaffected.

The results are in line with previous findings (cf. Chen et al. (2017)). It is important to control for unobserved heterogeneity in cash usage: The findings suggest a relationship between the adoption of contactless payment and decreasing cash usage if the endogenous choice of contactless payment is not accounted for. Omitted variables such as payment habitualization may also confound and bias the estimates. Therefore, the effect of contactless payment on cash demand is overestimated if unobserved heterogeneity is ignored.

Several caveats are worth mentioning. First, the dataset gives no insights into transactional purposes. Hence, the true values of cash purchases need to be proxied by the typical amount of cash per withdrawal, kept in wallet, and the frequency of withdrawals. These measures are not perfectly equivalent to the theoretical concept in the Baumol-Tobin framework. The difference between cash hoarding and cash usage for transactional purposes is likely to result in measurement errors. Incomplete information on the exact amount of 


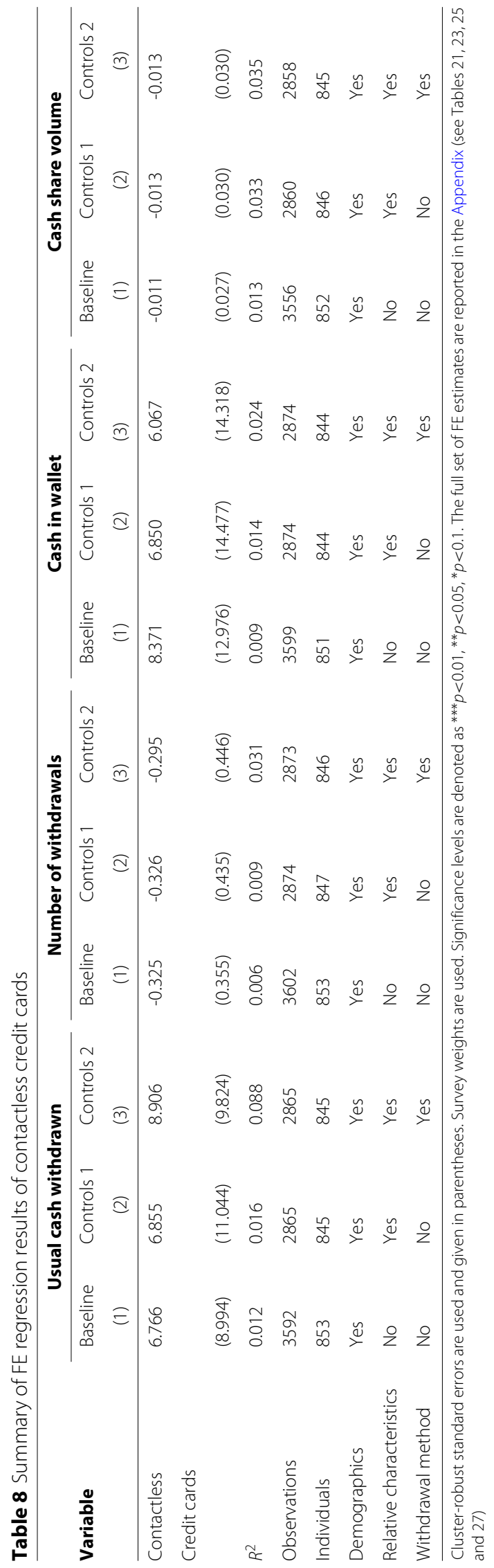


Table 9 Summary of FE regression results of contactless debit cards

\begin{tabular}{|c|c|c|c|c|c|c|c|c|c|c|c|c|}
\hline \multirow{3}{*}{ Variable } & \multicolumn{3}{|c|}{ Usual cash withdrawn } & \multicolumn{3}{|c|}{ Number of withdrawals } & \multicolumn{3}{|c|}{ Cash in wallet } & \multicolumn{3}{|c|}{ Cash share volume } \\
\hline & Baseline & $\begin{array}{l}\text { Controls } \\
1\end{array}$ & $\begin{array}{l}\text { Controls } \\
2\end{array}$ & Baseline & $\begin{array}{l}\text { Controls } \\
1\end{array}$ & $\begin{array}{l}\text { Controls } \\
2\end{array}$ & Baseline & $\begin{array}{l}\text { Controls } \\
1\end{array}$ & $\begin{array}{l}\text { Controls } \\
2\end{array}$ & Baseline & $\begin{array}{l}\text { Controls } \\
1\end{array}$ & $\begin{array}{l}\text { Controls } \\
2\end{array}$ \\
\hline & $(1)$ & $(2)$ & (3) & (1) & $(2)$ & (3) & (1) & (2) & (3) & (1) & (2) & (3) \\
\hline \multirow{2}{*}{$\begin{array}{l}\text { Contactless } \\
\text { debit cards }\end{array}$} & -2.250 & -2.966 & -5.062 & $-0.904^{*}$ & -0.942 & -0.941 & 3.789 & 4.256 & 3.206 & -0.003 & 0.003 & 0.004 \\
\hline & $(7.691)$ & $(7.751)$ & (7.725) & $(0.502)$ & $(0.634)$ & $(0.625)$ & $(5.966)$ & $(7.965)$ & (7.945) & $(0.033)$ & $(0.038)$ & $(0.038)$ \\
\hline$R^{2}$ & 0.012 & 0.011 & 0.067 & 0.008 & 0.015 & 0.041 & 0.011 & 0.014 & 0.020 & 0.013 & 0.028 & 0.030 \\
\hline Individuals & 3874 & 3084 & 3084 & 3882 & 3090 & 3089 & 3882 & 3093 & 3093 & 3832 & 3075 & 3074 \\
\hline Observations & 906 & 899 & 899 & 906 & 900 & 899 & 905 & 898 & 898 & 905 & 899 & 898 \\
\hline Demographics & Yes & Yes & Yes & Yes & Yes & Yes & Yes & Yes & Yes & Yes & Yes & Yes \\
\hline $\begin{array}{l}\text { Relative } \\
\text { characteristics }\end{array}$ & No & Yes & Yes & No & Yes & Yes & No & Yes & Yes & No & Yes & Yes \\
\hline $\begin{array}{l}\text { Withdrawal } \\
\text { method }\end{array}$ & No & No & Yes & No & No & Yes & No & No & Yes & No & No & Yes \\
\hline
\end{tabular}

Cluster-robust standard errors are used and given in parentheses. Survey weights are used. Significance levels are denoted as ${ }^{* * *} p<0.01,{ }^{* *} p<0.05,{ }^{*} p<0.1$. The full set of FE estimates are reported in the Appendix (see Tables 22, 24, 26, and 28)

checking account interest rates and household income may also lead to measurement errors. Measuring cash usage in terms of volume may also suffer from recall effects. Payment diaries reporting each transaction in detail, in conjunction with information on exact interest rates and income, would help to obtain more accurate results.

Second, the estimation results should be interpreted with caution since the diffusion of contactless payment cards and contactless-enabled terminals in the USA was still in its infancy in the years 2009-2013. It is likely that the effects are greater and also different if more cards are contactless and if consumers have readier access to more contactless-enabled terminals.

Third, appropriate instrumental variables were not available to properly control for possible reverse causality in the estimation. Individuals who rely less on cash may also adopt contactless payment to meet their personal preferences for frequent usage of payment cards. Plausible instrumental variables are necessary for future work: supply-side statistics come to mind (e.g., the number of contactless-enabled terminals differentiated by geographical region).

Fourth, the external validity of the results could be limited. This is because payment composition and payment infrastructure between the USA and Europe differ significantly due to their culturally and institutionally diverse evolution of payment systems. US Americans pay more by payment cards while Europeans rely heavily on cash as a payment means Bagnall et al. (2016). Therefore, specific payment patterns in the two payment areas may affect the magnitude of the estimated effects.

\section{Appendix}

\section{Variable definition}

\section{Household income}

Annual household income, as a proxy for consumption, is surveyed as a categorical variable with 17 categories. Interest rates of checking accounts are also reported as categories in the SCPC. I computed the average of each category's bounds to convert the categories into continuous variables. This makes interpreting the coefficients straightforward. Data for the median household income (over 200,000 USD) are drawn from the 2013 Survey of Consumer Finances as a proxy for the top income category (see SCF (2014)). I logarithmically transformed this variable for the estimation since test statistics conclude that the distribution of household income is skewed.

\section{Perceived characteristics}

The absolute ratings of the perceived characteristics of cash are transformed into relative ones-as in Schuh and Stavins (2013) - by using the following transformation:

$$
R C H A R_{k i}(j, h) \equiv \log \left(\frac{C H A R_{k i j}}{\sum_{h=1}^{H} C H A R_{k i h}}\right),
$$

where $k$ describes the six characteristics such as security, setup, acceptance, costs, records, and convenience, $i$ indexes the consumer, $j$ relates to cash, and $h$ is credit and debit cards. The construction is applied to every consumer regardless of the adoption stage of the payment methods. The higher the value of the variable $R C H A R_{k i}$, the more favorable cash is than debit and credit cards with respect to characteristic $k$. This normalizes the perception of a particular attribute.

\section{Descriptives and regression tables}


Table 10 First-year demographics of stayers vs. attritors

\begin{tabular}{|c|c|c|c|c|c|c|c|}
\hline \multirow[b]{2}{*}{ Variable } & \multicolumn{3}{|l|}{ Stayers } & \multicolumn{3}{|c|}{ Attritors } & \multirow{2}{*}{$\begin{array}{l}t \text { test } \\
\text { Mean diff }\end{array}$} \\
\hline & Mean & SD & $\mathbf{N}$ & Mean & SD & $\mathbf{N}$ & \\
\hline \multicolumn{8}{|l|}{ Income (in 1000) } \\
\hline$<25$ & 0.185 & 0.389 & 1128 & 0.181 & 0.386 & 1039 & -0.026 \\
\hline $0.3 \mathrm{~cm} \mathrm{25-49}$ & 0.358 & 0.480 & 1128 & 0.313 & 0.464 & 1039 & -0.014 \\
\hline $50-74$ & 0.219 & 0.414 & 1128 & 0.251 & 0.434 & 1039 & 0.029 \\
\hline $75-99$ & 0.132 & 0.338 & 1128 & 0.116 & 0.321 & 1039 & -0.025 \\
\hline $100-124$ & 0.037 & 0.188 & 1128 & 0.061 & 0.239 & 1039 & $0.026^{* *}$ \\
\hline $125-199$ & 0.049 & 0.216 & 1128 & 0.052 & 0.223 & 1039 & 0.009 \\
\hline$>200$ & 0.021 & 0.142 & 1128 & 0.025 & 0.158 & 1039 & 0.001 \\
\hline \multicolumn{8}{|l|}{ Education } \\
\hline$<$ High school & 0.046 & 0.209 & 1132 & 0.078 & 0.268 & 1041 & 0.023 \\
\hline High school & 0.432 & 0.496 & 1132 & 0.343 & 0.475 & 1041 & $-0.072^{*}$ \\
\hline Some college & 0.265 & 0.442 & 1132 & 0.292 & 0.455 & 1041 & 0.033 \\
\hline College & 0.168 & 0.374 & 1132 & 0.193 & 0.395 & 1041 & 0.015 \\
\hline Post graduate & 0.089 & 0.285 & 1132 & 0.093 & 0.291 & 1041 & 0.002 \\
\hline \multicolumn{8}{|l|}{ Employment } \\
\hline Working & 0.789 & 0.408 & 1018 & 0.753 & 0.431 & 959 & -0.036 \\
\hline Retired & 0.119 & 0.324 & 1018 & 0.168 & 0.374 & 959 & $0.050^{* *}$ \\
\hline Unemployed & 0.019 & 0.135 & 1018 & 0.005 & 0.074 & 959 & $-0.013^{*}$ \\
\hline Other & 0.062 & 0.242 & 1132 & 0.064 & 0.245 & 1041 & -0.001 \\
\hline \multicolumn{8}{|l|}{ Marital status } \\
\hline Single & 0.200 & 0.400 & 1132 & 0.195 & 0.396 & 1041 & 0.003 \\
\hline Married & 0.622 & 0.485 & 1132 & 0.641 & 0.480 & 1041 & 0.019 \\
\hline Separated & 0.134 & 0.340 & 1132 & 0.120 & 0.325 & 1041 & -0.021 \\
\hline Widowed & 0.044 & 0.206 & 1132 & 0.044 & 0.206 & 1041 & -0.001 \\
\hline \multicolumn{8}{|l|}{ Age } \\
\hline$<25$ & 0.099 & 0.299 & 1132 & 0.157 & 0.364 & 1040 & 0.047 \\
\hline $25-34$ & 0.178 & 0.383 & 1132 & 0.188 & 0.391 & 1040 & 0.026 \\
\hline $35-44$ & 0.186 & 0.389 & 1132 & 0.177 & 0.382 & 1040 & -0.013 \\
\hline $45-54$ & 0.239 & 0.427 & 1132 & 0.154 & 0.361 & 1040 & $-0.095^{* * *}$ \\
\hline $55-64$ & 0.135 & 0.342 & 1132 & 0.156 & 0.363 & 1040 & 0.015 \\
\hline$>65$ & 0.161 & 0.368 & 1132 & 0.167 & 0.373 & 1040 & 0.021 \\
\hline \multicolumn{8}{|l|}{ Ethnicity } \\
\hline White & 0.733 & 0.443 & 1132 & 0.750 & 0.433 & 1041 & 0.035 \\
\hline Black & 0.139 & 0.346 & 1132 & 0.098 & 0.298 & 1041 & $-0.064^{* *}$ \\
\hline Asian & 0.036 & 0.187 & 1132 & 0.030 & 0.171 & 1041 & -0.0001 \\
\hline Latino & 0.133 & 0.34 & 1132 & 0.168 & 0.374 & 1041 & 0.037 \\
\hline Other & 0.092 & 0.289 & 1132 & 0.122 & 0.327 & 1041 & 0.031 \\
\hline \multicolumn{8}{|l|}{ Others } \\
\hline Male & 0.485 & 0.500 & 1132 & 0.480 & 0.500 & 1041 & 0.004 \\
\hline HH members & 1.316 & 1.528 & 1132 & 1.331 & 1.584 & 1041 & 0.034 \\
\hline Revolver & 0.403 & 0.491 & 1122 & 0.403 & 0.491 & 1019 & -0.015 \\
\hline Home owner & 0.671 & 0.470 & 1129 & 0.693 & 0.462 & 1018 & 0.058 \\
\hline
\end{tabular}

$\mathrm{HH}$ refers to household. Survey weights used. $t$ tests of mean differences of stayers and attritors are displayed. Differences may stray from true values due to rounding and weighting. Significance levels are denoted as ${ }^{* * *} p<0.01,{ }^{* *} p<0.05,{ }^{*} p<0.1$. Variables are displayed for 2009 . Stayers participate five years in a row. Attritors participate in 2009 but not in all 5 years 
Table 11 First-year payment card and cash usage characteristics of stayers vs. attritors

\begin{tabular}{|c|c|c|c|c|c|c|c|}
\hline \multirow[b]{2}{*}{ Variable } & \multicolumn{3}{|l|}{ Stayers } & \multicolumn{3}{|l|}{ Attritors } & \multirow{2}{*}{$\begin{array}{l}t \text { test } \\
\text { Mean diff }\end{array}$} \\
\hline & Mean & SD & $\mathbf{N}$ & Mean & SD & $\mathbf{N}$ & \\
\hline Contactless credit cards & 0.103 & 0.303 & 1131 & 0.089 & 0.285 & 1027 & -0.015 \\
\hline Contactless debit cards & 0.099 & 0.298 & 1129 & 0.130 & 0.336 & 1029 & 0.034 \\
\hline Credit cards & 0.726 & 0.446 & 1131 & 0.717 & 0.451 & 1029 & -0.023 \\
\hline Debit cards & 0.757 & 0.429 & 1129 & 0.785 & 0.411 & 1028 & 0.029 \\
\hline Credit card usage & 0.567 & 0.496 & 1120 & 0.542 & 0.499 & 1019 & -0.036 \\
\hline Debit card usage & 0.641 & 0.480 & 1118 & 0.671 & 0.470 & 1019 & 0.033 \\
\hline Usual withdrawal & 122.368 & 161.119 & 1122 & 125.448 & 193.411 & 1023 & 3.974 \\
\hline Nr. of withdrawals & 3.258 & 2.956 & 1123 & 3.757 & 3.710 & 1023 & $0.479^{*}$ \\
\hline Cash in wallet & 72.698 & 120.903 & 1116 & 64.834 & 104.088 & 1016 & -8.315 \\
\hline Cash share in volume & 0.392 & 0.300 & 1074 & 0.36 & 0.301 & 968 & -0.027 \\
\hline
\end{tabular}

Usage describes the fact that respondents make the corresponding typ of payment at least once in a typical month. Survey weights used. $t$ tests of mean differences of stayers and attritors are displayed. Differences may stray from true values due to rounding and weighting. Significance levels are denoted as ${ }^{* * *} p<0.01,{ }^{* *} p<0.05,{ }^{*} p<0.1$. Variables are displayed for 2009. Stayers participate five years in a row. Attritors participate in 2009 but not in all 5 years 
Table 12 Sample summary statistics

\begin{tabular}{|c|c|c|c|c|c|c|c|c|c|}
\hline \multirow[b]{3}{*}{ Variable } & \multicolumn{3}{|c|}{ Entire sample } & \multicolumn{3}{|c|}{ Credit cards } & \multicolumn{3}{|c|}{ Debit cards } \\
\hline & & & & 1 & $\mathrm{~N}-\mathrm{I}$ & $t$ test & 1 & $\mathrm{~N}-\mathrm{I}$ & $t$ test \\
\hline & Mean & SD & $\mathbf{N}$ & Mean & Mean & Mean diff. & Mean & Mean & Mean diff. \\
\hline \multicolumn{10}{|l|}{ Income (in 1000) } \\
\hline$<25$ & 0.202 & 0.402 & 5645 & 0.140 & 0.209 & $-0.060^{* * *}$ & 0.302 & 0.189 & $0.115^{* * *}$ \\
\hline $25-49$ & 0.28 & 0.449 & 5645 & 0.253 & 0.283 & -0.029 & 0.285 & 0.280 & -0.004 \\
\hline $50-74$ & 0.199 & 0.4 & 5645 & 0.201 & 0.199 & 0.003 & 0.169 & 0.203 & -0.035 \\
\hline $75-99$ & 0.13 & 0.336 & 5645 & 0.133 & 0.129 & 0.001 & 0.097 & 0.134 & $-0.038^{* *}$ \\
\hline $100-124$ & 0.084 & 0.278 & 5645 & 0.090 & 0.084 & 0.004 & 0.058 & 0.088 & $-0.027^{*}$ \\
\hline $125-199$ & 0.076 & 0.264 & 5645 & 0.111 & 0.072 & $0.037^{* *}$ & 0.053 & 0.078 & $-0.024^{*}$ \\
\hline$>200$ & 0.029 & 0.169 & 5645 & 0.072 & 0.025 & $0.044^{* * *}$ & 0.037 & 0.029 & -0.012 \\
\hline \multicolumn{10}{|l|}{ Education } \\
\hline$<$ High school & 0.042 & 0.2 & 5660 & 0.058 & 0.040 & 0.025 & 0.059 & 0.040 & 0.019 \\
\hline High school & 0.379 & 0.485 & 5660 & 0.250 & 0.393 & $-0.132^{* * *}$ & 0.461 & 0.368 & $0.098^{* *}$ \\
\hline Some college & 0.278 & 0.448 & 5660 & 0.277 & 0.278 & -0.010 & 0.274 & 0.279 & -0.015 \\
\hline College & 0.171 & 0.377 & 5660 & 0.198 & 0.168 & 0.022 & 0.145 & 0.174 & -0.026 \\
\hline Post graduate & 0.13 & 0.336 & 5660 & 0.216 & 0.121 & $0.095^{* * *}$ & 0.060 & 0.138 & $-0.076^{* * *}$ \\
\hline \multicolumn{10}{|l|}{ Employment } \\
\hline Working & 0.648 & 0.478 & 5546 & 0.709 & 0.641 & $0.070^{* * *}$ & 0.733 & 0.637 & $0.099 * * *$ \\
\hline Retired & 0.208 & 0.406 & 5546 & 0.196 & 0.209 & -0.015 & 0.126 & 0.218 & $-0.088^{* * *}$ \\
\hline Unemployed & 0.062 & 0.242 & 5546 & 0.045 & 0.064 & -0.018 & 0.080 & 0.060 & 0.020 \\
\hline Other & 0.175 & 0.38 & 5660 & 0.140 & 0.178 & $-0.041^{* *}$ & 0.158 & 0.177 & -0.022 \\
\hline \multicolumn{10}{|l|}{ Marital status } \\
\hline Single & 0.142 & 0.349 & 5660 & 0.110 & 0.145 & $-0.030^{*}$ & 0.209 & 0.134 & 0.047 \\
\hline Married & 0.659 & 0.474 & 5660 & 0.674 & 0.657 & 0.010 & 0.610 & 0.664 & -0.027 \\
\hline Separated & 0.147 & 0.354 & 5660 & 0.145 & 0.148 & -0.005 & 0.166 & 0.145 & 0.016 \\
\hline Widowed & 0.052 & 0.222 & 5660 & 0.072 & 0.050 & $0.025^{*}$ & 0.015 & 0.056 & $-0.036^{* * *}$ \\
\hline \multicolumn{10}{|l|}{ Age } \\
\hline$<25$ & 0.045 & 0.206 & 5660 & 0.052 & 0.044 & 0.006 & 0.085 & 0.040 & 0.031 \\
\hline $25-34$ & 0.152 & 0.359 & 5660 & 0.119 & 0.155 & -0.031 & 0.245 & 0.139 & $0.095^{* *}$ \\
\hline $35-44$ & 0.169 & 0.375 & 5660 & 0.228 & 0.163 & $0.066^{* *}$ & 0.165 & 0.170 & -0.004 \\
\hline $45-54$ & 0.246 & 0.431 & 5660 & 0.242 & 0.246 & -0.010 & 0.271 & 0.243 & 0.041 \\
\hline $55-64$ & 0.182 & 0.386 & 5660 & 0.141 & 0.186 & $-0.042^{* *}$ & 0.114 & 0.190 & $-0.071^{* * *}$ \\
\hline$>65$ & 0.207 & 0.405 & 5660 & 0.219 & 0.206 & 0.012 & 0.120 & 0.218 & $-0.092^{* * *}$ \\
\hline \multicolumn{10}{|l|}{ Ethnicity } \\
\hline White & 0.765 & 0.424 & 5660 & 0.740 & 0.768 & -0.029 & 0.588 & 0.787 & $-0.201^{* * *}$ \\
\hline Black & 0.142 & 0.349 & 5660 & 0.076 & 0.149 & $-0.070^{* * *}$ & 0.198 & 0.133 & $0.065^{* *}$ \\
\hline Asian & 0.031 & 0.174 & 5660 & 0.104 & 0.024 & $0.074^{* * *}$ & 0.058 & 0.028 & $0.038^{* *}$ \\
\hline Latino & 0.093 & 0.29 & 5660 & 0.113 & 0.091 & 0.023 & 0.180 & 0.081 & $0.107^{* * *}$ \\
\hline Other & 0.062 & 0.241 & 5660 & 0.081 & 0.060 & 0.025 & 0.155 & 0.051 & $0.098^{* *}$ \\
\hline \multicolumn{10}{|l|}{ Others } \\
\hline Male & 0.452 & 0.498 & 5660 & 0.434 & 0.454 & -0.026 & 0.507 & 0.445 & 0.050 \\
\hline $\mathrm{HH}$ members & 1.276 & 1.566 & 5660 & 0.975 & 1.307 & $-0.353^{* * *}$ & 1.619 & 1.237 & $0.368^{* *}$ \\
\hline Revolver & 0.419 & 0.493 & 5602 & 0.499 & 0.410 & $0.086^{* * *}$ & 0.339 & 0.429 & $-0.078^{* *}$ \\
\hline Home owner & 0.71 & 0.454 & 5607 & 0.752 & 0.706 & $0.055^{*}$ & 0.499 & 0.737 & $-0.223^{* * *}$ \\
\hline
\end{tabular}

$\mathrm{N}-$ land / denote non-innovators and innovators, respectively. HH refers to household. The minimum numbers equal zero for every variable. Survey weights used. $t$ tests of mean differences of innovators and non-innovators are displayed. Differences may stray from true values due to rounding and weighting. Significance levels are denoted as ${ }^{* * *} p<0.01,{ }^{* *} p<0.05,{ }^{*} p<0.1$ 
Table 13 OLS regression results of contactless credit on usual cash withdrawn

\begin{tabular}{|c|c|c|c|c|c|c|}
\hline \multirow[b]{2}{*}{ Variable } & \multicolumn{2}{|l|}{ (1) } & \multicolumn{2}{|l|}{ (2) } & \multicolumn{2}{|l|}{ (3) } \\
\hline & $b$ & se & $b$ & se & $b$ & se \\
\hline Contactless credit & -5.301 & (14.613) & -5.507 & $(14.760)$ & -10.587 & (15.396) \\
\hline $\log ($ income) & $30.885^{* * *}$ & (6.308) & $35.589^{* * *}$ & $(6.301)$ & $37.976^{* * *}$ & $(6.451)$ \\
\hline Interest rate & -6.433 & $(11.463)$ & -5.329 & $(10.787)$ & -1.799 & $(9.505)$ \\
\hline \multicolumn{7}{|l|}{ Education } \\
\hline High school & -24.227 & $(31.741)$ & -23.819 & (33.539) & -16.421 & (36.158) \\
\hline Some college & -14.669 & $(32.814)$ & -13.565 & (34.835) & -10.931 & (37.197) \\
\hline College & -33.381 & (33.496) & -28.655 & $(35.686)$ & -20.106 & $(38.322)$ \\
\hline Post graduate & -10.333 & $(35.484)$ & -6.421 & $(37.492)$ & 1.853 & $(40.304)$ \\
\hline \multicolumn{7}{|l|}{ Employment } \\
\hline Working & $-24.375^{*}$ & (13.123) & $-23.459^{*}$ & $(13.400)$ & $-23.946^{* *}$ & (12.172) \\
\hline Retired & 3.797 & $(24.020)$ & 7.888 & (23.649) & 9.055 & (23.476) \\
\hline Other & $31.713^{* *}$ & (15.364) & $35.325^{* *}$ & $(15.512)$ & $33.888^{* *}$ & $(15.257)$ \\
\hline \multicolumn{7}{|l|}{ Marital status } \\
\hline Single & -35.151 & (34.478) & -32.307 & (33.662) & -33.348 & $(30.590)$ \\
\hline Married & $-57.976^{*}$ & $(32.407)$ & $-58.621^{*}$ & $(31.320)$ & $-59.704^{* *}$ & $(29.269)$ \\
\hline Separated & -27.190 & (34.106) & -22.297 & (33.602) & -16.506 & $(30.831)$ \\
\hline \multicolumn{7}{|l|}{ Age } \\
\hline $25-34$ & 15.620 & (19.975) & 22.015 & $(20.370)$ & $36.509^{* *}$ & (18.243) \\
\hline $35-44$ & 11.993 & (22.396) & 15.083 & $(22.467)$ & $34.465^{*}$ & (19.610) \\
\hline $45-54$ & $38.200^{*}$ & (22.869) & 36.187 & $(22.962)$ & $39.305^{* *}$ & (20.018) \\
\hline $55-64$ & 36.924 & $(25.361)$ & 31.116 & $(25.617)$ & 34.154 & (22.811) \\
\hline$>65$ & 44.779 & (31.808) & 30.569 & (32.846) & 31.962 & (30.458) \\
\hline \multicolumn{7}{|l|}{ Ethnicity } \\
\hline White & -21.338 & $(44.445)$ & -22.980 & $(45.108)$ & -30.039 & $(45.024)$ \\
\hline Black & 0.618 & $(48.577)$ & -5.700 & $(48.927)$ & -10.741 & $(48.945)$ \\
\hline Latino & 23.720 & (15.654) & 18.551 & (14.956) & 21.396 & (14.878) \\
\hline Other & -26.842 & (47.219) & -28.048 & (48.138) & -33.685 & $(48.045)$ \\
\hline \multicolumn{7}{|l|}{ Other } \\
\hline Male & $25.931^{* * *}$ & (9.259) & $27.375^{* * *}$ & $(9.215)$ & $22.688^{* *}$ & $(8.926)$ \\
\hline $\mathrm{HH}$ members & 0.582 & (4.399) & -0.194 & $(4.387)$ & -1.627 & $(4.491)$ \\
\hline CC revolver & $-41.217^{* * *}$ & (9.535) & $-38.676^{* * *}$ & $(9.681)$ & $-30.695^{* * *}$ & $(9.370)$ \\
\hline Home owner & 17.532 & (12.353) & 16.992 & $(12.130)$ & 11.995 & (11.307) \\
\hline \multicolumn{7}{|l|}{ Rel. characteristics } \\
\hline Security & & & $19.570^{* * *}$ & $(7.492)$ & $14.066^{* *}$ & $(6.883)$ \\
\hline Setup & & & -18.465 & (11.395) & $-32.118^{* * *}$ & (11.052) \\
\hline Acceptance & & & 22.753 & $(16.290)$ & 22.957 & (16.678) \\
\hline Costs & & & -1.936 & (13.064) & -2.073 & (12.444) \\
\hline Records & & & 13.911 & (8.519) & 6.240 & $(8.207)$ \\
\hline Convenience & & & $37.702^{* * *}$ & $(11.137)$ & $33.056^{* * *}$ & $(10.417)$ \\
\hline \multicolumn{7}{|l|}{ Withdrawal method } \\
\hline Bank teller & & & & & $83.374^{* * *}$ & (13.958) \\
\hline Check casher & & & & & $209.064^{* * *}$ & $(60.061)$ \\
\hline Cashback & & & & & $-60.506^{* * *}$ & $(7.440)$ \\
\hline Employer & & & & & $103.629^{* *}$ & $(40.740)$ \\
\hline Family & & & & & 8.894 & (28.750) \\
\hline Other & & & & & $98.102^{* *}$ & $(45.644)$ \\
\hline Constant & $-154.330^{*}$ & (88.997) & -130.304 & (90.618) & $-206.721^{* *}$ & $(94.081)$ \\
\hline$R^{2}$ & 0.083 & & 0.112 & & 0.208 & \\
\hline Individuals & 1464 & & 1452 & & 1452 & \\
\hline
\end{tabular}

$b$ are the point estimates and se the standard errors. Cluster-robust standard errors and survey weights are used. $\mathrm{HH}$ and CC refers to household and credit card, respectively. Base category of categorical variables is lower than high school, unemployed, widowed, lower than 25 years, Asian, and ATM. Significance levels are denoted as ${ }^{* * *} p<0.01$, ${ }^{*} p<0.05,{ }^{*} p<0.1$ 
Table 14 OLS regression results of contactless debit on usual cash withdrawn

\begin{tabular}{|c|c|c|c|c|c|c|}
\hline \multirow[b]{2}{*}{ Variable } & \multicolumn{2}{|l|}{ (1) } & \multicolumn{2}{|l|}{ (2) } & \multicolumn{2}{|l|}{ (3) } \\
\hline & $\boldsymbol{b}$ & se & $b$ & se & $b$ & se \\
\hline Contactless debit & -0.289 & (15.510) & 1.223 & (15.558) & 9.603 & (14.638) \\
\hline $\log$ (income) & $30.668^{* * *}$ & $(6.243)$ & $35.371^{* * *}$ & $(6.236)$ & $37.663^{* * *}$ & $(6.382)$ \\
\hline Interest rate & -6.450 & (11.468) & -5.359 & (10.789) & -1.879 & $(9.476)$ \\
\hline \multicolumn{7}{|l|}{ Education } \\
\hline High school & -23.307 & $(32.287)$ & -22.802 & (34.366) & -14.868 & (36.797) \\
\hline Some college & -13.768 & (33.322) & -12.553 & (35.593) & -9.257 & $(37.827)$ \\
\hline College & -32.630 & (33.807) & -27.787 & (36.219) & -18.655 & (38.716) \\
\hline Post graduate & -9.745 & (35.788) & -5.694 & (37.963) & 3.112 & (40.608) \\
\hline \multicolumn{7}{|l|}{ Employment } \\
\hline Working & $-24.510^{*}$ & $(13.185)$ & $-23.680^{*}$ & $(13.460)$ & $-24.508^{* *}$ & $(12.242)$ \\
\hline Retired & 3.974 & (23.963) & 8.098 & (23.549) & 9.707 & (23.396) \\
\hline Other & $31.836^{* *}$ & (15.398) & $35.356^{* *}$ & $(15.511)$ & $33.521^{* *}$ & (15.309) \\
\hline \multicolumn{7}{|l|}{ Marital status } \\
\hline Single & -35.054 & $(34.424)$ & -32.225 & (33.655) & -32.793 & (30.590) \\
\hline Married & $-57.853^{*}$ & (32.409) & $-58.531^{*}$ & (31.351) & $-59.349^{* *}$ & (29.342) \\
\hline Separated & -27.270 & (34.134) & -22.438 & (33.636) & -16.686 & (30.905) \\
\hline \multicolumn{7}{|l|}{ Age } \\
\hline $25-34$ & 15.708 & (19.864) & 21.953 & (20.344) & $36.273^{* *}$ & (18.138) \\
\hline $35-44$ & 12.183 & $(22.272)$ & 15.325 & $(22.446)$ & $35.682^{*}$ & (19.596) \\
\hline $45-54$ & $38.522^{*}$ & $(22.684)$ & 36.575 & (22.859) & $40.826^{* *}$ & (19.913) \\
\hline $55-64$ & 37.198 & $(25.172)$ & 31.414 & $(25.512)$ & 35.368 & $(22.644)$ \\
\hline$>65$ & 44.811 & $(31.841)$ & 30.574 & (32.932) & 32.553 & (30.558) \\
\hline \multicolumn{7}{|l|}{ Ethnicity } \\
\hline White & -20.823 & $(44.223)$ & -22.444 & $(44.902)$ & -28.547 & $(44.897)$ \\
\hline Black & 1.536 & $(47.930)$ & -4.914 & (48.348) & -9.532 & $(48.363)$ \\
\hline Latino & 23.581 & (15.556) & 18.363 & $(14.851)$ & 20.854 & $(14.828)$ \\
\hline Other & -26.397 & $(46.944)$ & -27.731 & (47.925) & -33.294 & $(47.947)$ \\
\hline \multicolumn{7}{|l|}{ Other } \\
\hline Male & $25.788^{* * *}$ & $(9.225)$ & $27.224^{* * *}$ & $(9.187)$ & $22.361^{* *}$ & $(8.901)$ \\
\hline HH members & 0.623 & $(4.312)$ & -0.164 & $(4.309)$ & -1.601 & $(4.375)$ \\
\hline CC revolver & $-41.239^{* * *}$ & $(9.468)$ & $-38.696^{* * *}$ & $(9.623)$ & $-30.571^{* * *}$ & $(9.314)$ \\
\hline Home owner & 17.635 & $(12.448)$ & 17.170 & $(12.158)$ & 12.646 & $(11.296)$ \\
\hline \multicolumn{7}{|l|}{ Rel. characteristics } \\
\hline Security & & & $19.551^{* * *}$ & $(7.470)$ & $13.900^{* *}$ & $(6.843)$ \\
\hline Setup & & & $-18.688^{*}$ & $(11.126)$ & $-32.062^{* * *}$ & $(10.874)$ \\
\hline Acceptance & & & 22.779 & (16.298) & 22.936 & (16.708) \\
\hline Costs & & & -1.600 & (13.078) & -1.383 & (12.515) \\
\hline Records & & & 13.805 & (8.518) & 5.961 & $(8.191)$ \\
\hline Convenience & & & $37.822^{* * *}$ & $(11.228)$ & $33.467^{* * *}$ & $(10.451)$ \\
\hline \multicolumn{7}{|l|}{ Withdrawal method } \\
\hline Bank teller & & & & & $83.496^{* * *}$ & (14.043) \\
\hline Check casher & & & & & $211.711^{* * *}$ & $(59.847)$ \\
\hline Cashback & & & & & $-59.936^{* * *}$ & $(7.464)$ \\
\hline Employer & & & & & $105.128^{* *}$ & (40.819) \\
\hline Family & & & & & 10.774 & $(29.041)$ \\
\hline Other & & & & & $98.630^{* *}$ & $(45.704)$ \\
\hline Constant & $-154.078^{*}$ & (89.384) & -130.316 & (90.949) & $-209.598^{* *}$ & (94.679) \\
\hline$R^{2}$ & 0.083 & & 0.112 & & 0.208 & \\
\hline Individuals & 1464 & & 1452 & & 1452 & \\
\hline
\end{tabular}


Table 15 OLS regression results of contactless credit on number of withdrawals

\begin{tabular}{|c|c|c|c|c|c|c|}
\hline \multirow[b]{2}{*}{ Variable } & \multicolumn{2}{|l|}{ (1) } & \multicolumn{2}{|l|}{ (2) } & \multicolumn{2}{|l|}{ (3) } \\
\hline & $b$ & se & $b$ & se & $b$ & se \\
\hline Contactless credit & -0.723 & $(0.667)$ & -0.611 & $(0.619)$ & -0.455 & $(0.607)$ \\
\hline $\log ($ income) & -0.816 & $(0.543)$ & -0.880 & $(0.547)$ & $-0.804^{*}$ & $(0.456)$ \\
\hline Interest rate & -0.216 & $(0.345)$ & -0.210 & $(0.358)$ & -0.132 & $(0.360)$ \\
\hline \multicolumn{7}{|l|}{ Education } \\
\hline High school & -4.241 & $(3.365)$ & -1.537 & $(1.920)$ & -1.858 & $(1.803)$ \\
\hline Some college & -5.073 & $(3.278)$ & -2.369 & $(1.795)$ & -2.621 & $(1.742)$ \\
\hline College & -4.302 & $(3.217)$ & -1.714 & $(1.846)$ & -1.946 & $(1.754)$ \\
\hline Post graduate & -4.301 & $(3.332)$ & -1.636 & $(1.965)$ & -1.938 & $(1.811)$ \\
\hline \multicolumn{7}{|l|}{ Employment } \\
\hline Working & $1.685^{*}$ & $(0.999)$ & 0.957 & $(0.691)$ & 0.671 & $(0.637)$ \\
\hline Retired & 0.782 & $(1.170)$ & -0.390 & $(0.587)$ & -0.386 & $(0.603)$ \\
\hline Other & 0.341 & $(1.032)$ & -0.550 & $(0.606)$ & -0.591 & $(0.597)$ \\
\hline \multicolumn{7}{|l|}{ Marital status } \\
\hline Single & -0.181 & $(2.167)$ & -0.463 & $(2.130)$ & -0.464 & $(2.148)$ \\
\hline Married & -1.721 & $(1.933)$ & -2.179 & $(1.859)$ & -2.166 & $(1.873)$ \\
\hline Separated & -2.621 & $(2.038)$ & -2.909 & $(2.016)$ & -2.781 & $(2.041)$ \\
\hline \multicolumn{7}{|l|}{ Age } \\
\hline $25-34$ & -1.942 & $(2.781)$ & -2.190 & $(2.776)$ & -1.676 & $(2.410)$ \\
\hline $35-44$ & -0.964 & $(2.584)$ & -0.989 & $(2.533)$ & -0.581 & $(2.246)$ \\
\hline $45-54$ & -0.614 & $(2.681)$ & -1.013 & $(2.552)$ & -0.614 & $(2.277)$ \\
\hline $55-64$ & -1.012 & $(2.581)$ & -1.166 & $(2.455)$ & -0.866 & $(2.181)$ \\
\hline$>65$ & -0.767 & $(2.692)$ & -1.088 & $(2.424)$ & -0.561 & $(2.153)$ \\
\hline \multicolumn{7}{|l|}{ Ethnicity } \\
\hline White & 0.788 & $(1.041)$ & 0.950 & $(1.092)$ & 0.587 & $(0.952)$ \\
\hline Black & $4.407^{* *}$ & $(1.840)$ & $3.045^{* *}$ & $(1.532)$ & $2.715^{*}$ & $(1.474)$ \\
\hline Latino & 0.314 & $(0.633)$ & 0.484 & $(0.573)$ & 0.409 & $(0.587)$ \\
\hline Other & $5.129^{* *}$ & $(2.397)$ & $5.319^{* *}$ & $(2.460)$ & $4.874^{* *}$ & $(2.155)$ \\
\hline \multicolumn{7}{|l|}{ Other } \\
\hline Male & $0.985^{*}$ & $(0.586)$ & 0.728 & $(0.509)$ & 0.578 & $(0.463)$ \\
\hline $\mathrm{HH}$ members & -0.103 & $(0.197)$ & -0.133 & $(0.203)$ & -0.104 & $(0.200)$ \\
\hline CC revolver & -0.636 & $(0.429)$ & -0.519 & $(0.433)$ & -0.455 & $(0.451)$ \\
\hline Home owner & $-1.527^{* *}$ & $(0.773)$ & $-1.125^{*}$ & $(0.628)$ & -0.962 & $(0.670)$ \\
\hline \multicolumn{7}{|l|}{ Rel. characteristics } \\
\hline Security & & & 0.131 & $(0.287)$ & 0.051 & $(0.285)$ \\
\hline Setup & & & -0.098 & $(0.729)$ & -0.098 & $(0.718)$ \\
\hline Acceptance & & & -0.937 & $(0.777)$ & -0.971 & $(0.735)$ \\
\hline Costs & & & -0.547 & $(0.661)$ & -0.370 & $(0.586)$ \\
\hline Records & & & -0.029 & $(0.423)$ & -0.109 & $(0.406)$ \\
\hline Convenience & & & 0.456 & $(0.702)$ & 0.510 & $(0.701)$ \\
\hline \multicolumn{7}{|l|}{ Withdrawal method } \\
\hline Bank teller & & & & & -0.394 & $(0.524)$ \\
\hline Check casher & & & & & 14.496 & $(11.068)$ \\
\hline Cashback & & & & & -0.019 & $(0.759)$ \\
\hline Employer & & & & & 1.186 & $(1.587)$ \\
\hline Family & & & & & -0.932 & $(1.013)$ \\
\hline Other & & & & & 2.537 & $(1.799)$ \\
\hline Constant & $18.501^{* * *}$ & $(6.682)$ & $17.340^{* * *}$ & $(6.624)$ & $16.594^{* * *}$ & $(5.579)$ \\
\hline$R^{2}$ & 0.092 & & 0.086 & & 0.111 & \\
\hline Individuals & 1464 & & 1452 & & 1452 & \\
\hline
\end{tabular}


Table 16 OLS regression results of contactless debit on number of withdrawals

\begin{tabular}{|c|c|c|c|c|c|c|}
\hline \multirow[b]{2}{*}{ Variable } & \multicolumn{2}{|l|}{ (1) } & \multicolumn{2}{|l|}{ (2) } & \multicolumn{2}{|l|}{ (3) } \\
\hline & $b$ & se & $b$ & se & $b$ & se \\
\hline Contactless debit & 1.043 & (1.299) & 0.028 & (0.899) & 0.156 & $(0.863)$ \\
\hline $\log ($ income) & -0.840 & $(0.546)$ & -0.905 & $(0.553)$ & $-0.820^{*}$ & $(0.457)$ \\
\hline Interest rate & -0.232 & $(0.354)$ & -0.212 & $(0.359)$ & -0.134 & $(0.362)$ \\
\hline \multicolumn{7}{|l|}{ Education } \\
\hline High school & -4.155 & (3.334) & -1.417 & $(1.916)$ & -1.775 & (1.778) \\
\hline Some college & -4.972 & $(3.227)$ & -2.250 & $(1.775)$ & -2.536 & $(1.705)$ \\
\hline College & -4.213 & $(3.171)$ & -1.613 & $(1.835)$ & -1.873 & $(1.726)$ \\
\hline Post graduate & -4.218 & (3.283) & -1.551 & $(1.963)$ & -1.876 & $(1.793)$ \\
\hline \multicolumn{7}{|l|}{ Employment } \\
\hline Working & $1.622^{*}$ & $(0.961)$ & 0.935 & $(0.687)$ & 0.653 & $(0.630)$ \\
\hline Retired & 0.796 & (1.158) & -0.368 & $(0.589)$ & -0.362 & $(0.608)$ \\
\hline Other & 0.279 & $(0.972)$ & -0.540 & $(0.606)$ & -0.592 & $(0.596)$ \\
\hline \multicolumn{7}{|l|}{ Marital status } \\
\hline Single & -0.137 & $(2.173)$ & -0.458 & (2.130) & -0.450 & $(2.147)$ \\
\hline Married & -1.700 & (1.933) & -2.170 & $(1.859)$ & -2.154 & $(1.873)$ \\
\hline Separated & -2.652 & $(2.035)$ & -2.923 & $(2.017)$ & -2.788 & $(2.042)$ \\
\hline \multicolumn{7}{|l|}{ Age } \\
\hline $25-34$ & -2.019 & $(2.755)$ & -2.189 & $(2.748)$ & -1.672 & $(2.391)$ \\
\hline $35-44$ & -0.903 & $(2.610)$ & -0.967 & $(2.552)$ & -0.546 & $(2.265)$ \\
\hline $45-54$ & -0.518 & $(2.720)$ & -0.976 & $(2.575)$ & -0.568 & (2.299) \\
\hline $55-64$ & -0.943 & $(2.608)$ & -1.138 & $(2.471)$ & -0.827 & $(2.195)$ \\
\hline$>65$ & -0.731 & $(2.725)$ & -1.092 & $(2.448)$ & -0.548 & $(2.172)$ \\
\hline \multicolumn{7}{|l|}{ Ethnicity } \\
\hline White & 0.900 & $(1.025)$ & 1.006 & $(1.084)$ & 0.641 & $(0.945)$ \\
\hline Black & $4.444^{* *}$ & $(1.815)$ & $3.140^{* *}$ & $(1.553)$ & $2.783^{*}$ & $(1.495)$ \\
\hline Latino & 0.258 & $(0.645)$ & 0.466 & $(0.580)$ & 0.393 & $(0.594)$ \\
\hline Other & $5.126^{* *}$ & $(2.426)$ & $5.360^{* *}$ & $(2.488)$ & $4.904^{* *}$ & $(2.175)$ \\
\hline \multicolumn{7}{|l|}{ Other } \\
\hline Male & 0.952 & $(0.580)$ & 0.712 & $(0.509)$ & 0.567 & $(0.463)$ \\
\hline $\mathrm{HH}$ members & -0.103 & $(0.196)$ & -0.130 & $(0.201)$ & -0.102 & $(0.197)$ \\
\hline CC revolver & -0.618 & $(0.424)$ & -0.523 & $(0.437)$ & -0.455 & $(0.455)$ \\
\hline Home owner & $-1.463^{* *}$ & $(0.742)$ & $-1.110^{*}$ & $(0.629)$ & -0.943 & $(0.669)$ \\
\hline \multicolumn{7}{|l|}{ Rel. characteristics } \\
\hline Security & & & 0.131 & $(0.284)$ & 0.048 & $(0.281)$ \\
\hline Setup & & & -0.131 & $(0.745)$ & -0.112 & $(0.731)$ \\
\hline Acceptance & & & -0.934 & $(0.775)$ & -0.972 & $(0.730)$ \\
\hline Costs & & & -0.509 & $(0.658)$ & -0.340 & $(0.586)$ \\
\hline Records & & & -0.040 & $(0.423)$ & -0.118 & $(0.405)$ \\
\hline Convenience & & & 0.467 & $(0.712)$ & 0.521 & $(0.710)$ \\
\hline \multicolumn{7}{|l|}{ Withdrawal method } \\
\hline Bank teller & & & & & -0.397 & $(0.521)$ \\
\hline Check casher & & & & & 14.577 & (11.053) \\
\hline Cashback & & & & & 0.005 & $(0.762)$ \\
\hline Employer & & & & & 1.233 & $(1.576)$ \\
\hline Family & & & & & -0.869 & $(1.015)$ \\
\hline Other & & & & & 2.551 & $(1.801)$ \\
\hline Constant & $18.355^{* * *}$ & $(6.748)$ & $17.354^{* * *}$ & $(6.673)$ & $16.527^{* * *}$ & $(5.613)$ \\
\hline$R^{2}$ & 0.093 & & 0.085 & & 0.110 & \\
\hline Individuals & 1464 & & 1452 & & 1452 & \\
\hline
\end{tabular}

$b$ are the point estimates and se the standard errors. Cluster-robust standard errors and survey weights are used. $\mathrm{HH}$ and CC refers to household and credit card, respectively. Base category of categorical variables is lower than high school, unemployed, widowed, lower than 25 years, Asian and ATM. Significance levels are denoted as ${ }^{* * *} p<0.01$, ${ }^{* *} p<0.05,{ }^{*} p<0.1$ 
Table 17 OLS regression results of contactless credit on cash in wallet

\begin{tabular}{|c|c|c|c|c|c|c|}
\hline \multirow[b]{2}{*}{ Variable } & \multicolumn{2}{|l|}{ (1) } & \multicolumn{2}{|l|}{ (2) } & \multicolumn{2}{|l|}{ (3) } \\
\hline & $\mathbf{b}$ & se & $\mathbf{b}$ & se & $\mathbf{b}$ & se \\
\hline Contactless credit & 3.606 & (9.568) & 4.114 & $(9.588)$ & 3.644 & $(9.590)$ \\
\hline $\log ($ income) & $22.446^{* * *}$ & $(4.547)$ & $22.969^{* * *}$ & $(4.569)$ & $23.999 * * *$ & $(4.627)$ \\
\hline Interest rate & 0.189 & $(4.865)$ & -0.159 & $(5.080)$ & 1.013 & $(5.229)$ \\
\hline \multicolumn{7}{|l|}{ Education } \\
\hline High school & 3.021 & $(19.040)$ & 5.792 & $(19.713)$ & 7.755 & (20.328) \\
\hline Some college & -1.895 & (19.759) & 1.181 & $(20.455)$ & 2.198 & (21.104) \\
\hline College & 6.686 & $(20.460)$ & 10.365 & $(21.135)$ & 12.963 & (21.838) \\
\hline Post graduate & -0.388 & (21.309) & 3.125 & $(21.859)$ & 5.460 & $(22.622)$ \\
\hline \multicolumn{7}{|l|}{ Employment } \\
\hline Working & -0.812 & (7.003) & -1.902 & $(6.968)$ & -2.606 & $(6.863)$ \\
\hline Retired & 4.829 & $(12.600)$ & 7.901 & $(12.779)$ & 8.339 & (12.343) \\
\hline Other & 5.847 & (7.943) & 6.809 & $(7.767)$ & 6.417 & $(7.663)$ \\
\hline \multicolumn{7}{|l|}{ Marital status } \\
\hline Single & -23.529 & $(16.831)$ & -22.292 & $(16.930)$ & -22.157 & (16.365) \\
\hline Married & $-37.789^{* *}$ & $(15.762)$ & $-36.988^{* *}$ & $(15.771)$ & $-36.980^{* *}$ & $(15.222)$ \\
\hline Separated & -19.454 & (15.889) & -16.866 & (15.985) & -14.790 & (15.458) \\
\hline \multicolumn{7}{|l|}{ Age } \\
\hline $25-34$ & -8.511 & $(12.364)$ & -8.941 & $(12.580)$ & -2.698 & $(11.661)$ \\
\hline $35-44$ & 0.027 & (13.513) & -0.100 & $(13.677)$ & 7.076 & (12.889) \\
\hline $45-54$ & 10.213 & (13.987) & 9.080 & (14.195) & 11.900 & (13.194) \\
\hline $55-64$ & $25.764^{*}$ & (14.509) & 23.771 & $(14.812)$ & $26.734^{*}$ & (13.945) \\
\hline$>65$ & 27.009 & $(17.671)$ & 21.299 & $(17.972)$ & 23.995 & $(17.261)$ \\
\hline \multicolumn{7}{|l|}{ Ethnicity } \\
\hline White & -11.911 & (15.435) & -11.541 & (15.553) & -13.642 & (15.659) \\
\hline Black & -13.987 & (16.829) & -13.339 & $(16.991)$ & -14.787 & (17.077) \\
\hline Latino & -2.992 & $(7.632)$ & -2.791 & $(7.856)$ & -2.092 & (7.895) \\
\hline Other & -4.479 & $(17.283)$ & -5.710 & $(17.424)$ & -7.681 & (17.707) \\
\hline \multicolumn{7}{|l|}{ Other } \\
\hline Male & $31.668^{* * *}$ & $(4.811)$ & $30.825^{* * *}$ & $(4.872)$ & $29.563^{* * *}$ & $(4.812)$ \\
\hline $\mathrm{HH}$ members & 1.085 & $(2.962)$ & 0.912 & $(2.918)$ & 0.629 & $(2.942)$ \\
\hline CC revolver & $-15.320^{* * *}$ & $(5.121)$ & $-14.110^{* * *}$ & $(5.244)$ & $-12.023^{* *}$ & (5.169) \\
\hline Home owner & $17.379^{* * *}$ & $(5.441)$ & $15.936^{* * *}$ & (5.395) & $15.149^{* * *}$ & $(4.984)$ \\
\hline \multicolumn{7}{|l|}{ Rel. characteristics } \\
\hline Security & & & -0.793 & (3.269) & -2.355 & $(3.236)$ \\
\hline Setup & & & -3.409 & $(6.377)$ & -7.041 & (6.319) \\
\hline Acceptance & & & 1.427 & $(9.089)$ & 0.830 & $(9.227)$ \\
\hline Costs & & & -8.512 & $(7.372)$ & -7.981 & $(7.201)$ \\
\hline Records & & & 0.457 & $(4.830)$ & -1.543 & $(4.720)$ \\
\hline Convenience & & & $12.896^{*}$ & $(6.699)$ & $11.800^{*}$ & $(6.435)$ \\
\hline \multicolumn{7}{|l|}{ Withdrawal method } \\
\hline Bank teller & & & & & $20.917^{* * *}$ & $(6.983)$ \\
\hline Check casher & & & & & $94.271^{* *}$ & $(40.477)$ \\
\hline Cashback & & & & & $-13.049^{* *}$ & (6.096) \\
\hline Employer & & & & & $36.990^{* *}$ & (15.603) \\
\hline Family & & & & & 4.733 & $(10.735)$ \\
\hline Other & & & & & 28.496 & (19.593) \\
\hline Constant & $-176.079^{* * *}$ & $(49.450)$ & $-177.989^{* * *}$ & $(50.897)$ & $-206.114^{* * *}$ & $(52.532)$ \\
\hline$R^{2}$ & 0.153 & & 0.155 & & 0.182 & \\
\hline Individuals & 1465 & & 1453 & & 1453 & \\
\hline
\end{tabular}

$b$ are the point estimates and se the standard errors. Cluster-robust standard errors and survey weights are used. $\mathrm{HH}$ and CC refers to household and credit card, respectively. Base category of categorical variables is lower than high school, unemployed, widowed, lower than 25 years, Asian, and ATM. Significance levels are denoted as ${ }^{* * *} p<0.01$, ${ }^{*} p<0.05,{ }^{*} p<0.1$ 
Table 18 OLS regression results of contactless debit on cash in wallet

\begin{tabular}{|c|c|c|c|c|c|c|}
\hline \multirow[b]{2}{*}{ Variable } & \multicolumn{2}{|l|}{ (1) } & \multicolumn{2}{|l|}{ (2) } & \multicolumn{2}{|l|}{ (3) } \\
\hline & b & se & b & se & b & se \\
\hline Contactless debit & -4.297 & (8.632) & -2.101 & (8.698) & 0.426 & $(8.579)$ \\
\hline $\log ($ income) & $22.570^{* * *}$ & $(4.533)$ & $23.138^{* * *}$ & $(4.532)$ & $24.163^{* * *}$ & $(4.586)$ \\
\hline Interest rate & 0.261 & $(4.868)$ & -0.116 & $(5.072)$ & 1.036 & $(5.223)$ \\
\hline \multicolumn{7}{|l|}{ Education } \\
\hline High school & 2.530 & (19.833) & 5.129 & (20.836) & 7.041 & (21.495) \\
\hline Some college & -2.438 & (20.582) & 0.488 & $(21.607)$ & 1.440 & $(22.324)$ \\
\hline College & 6.204 & (21.106) & 9.803 & $(22.082)$ & 12.375 & (22.850) \\
\hline Post graduate & -0.831 & $(21.867)$ & 2.645 & (22.718) & 4.967 & $(23.545)$ \\
\hline \multicolumn{7}{|l|}{ Employment } \\
\hline Working & -0.532 & $(7.003)$ & -1.727 & (6.989) & -2.544 & (6.873) \\
\hline Retired & 4.759 & $(12.582)$ & 7.709 & (12.759) & 8.146 & (12.309) \\
\hline Other & 6.109 & (8.026) & 6.877 & $(7.822)$ & 6.326 & $(7.713)$ \\
\hline \multicolumn{7}{|l|}{ Marital status } \\
\hline Single & -23.694 & (16.853) & -22.452 & $(16.982)$ & -22.318 & (16.391) \\
\hline Married & $-37.883^{* *}$ & (15.795) & $-37.085^{* *}$ & (15.815) & $-37.094^{* *}$ & (15.245) \\
\hline Separated & -19.301 & $(15.917)$ & -16.765 & (16.034) & -14.785 & (15.485) \\
\hline \multicolumn{7}{|l|}{ Age } \\
\hline $25-34$ & -8.175 & (12.195) & -8.866 & (12.419) & -2.950 & (11.503) \\
\hline $35-44$ & -0.213 & (13.365) & -0.347 & (13.579) & 6.858 & (12.795) \\
\hline $45-54$ & 9.806 & $(13.872)$ & 8.696 & $(14.121)$ & 11.577 & (13.133) \\
\hline $55-64$ & $25.473^{*}$ & (14.316) & 23.488 & (14.655) & $26.461^{*}$ & (13.766) \\
\hline$>65$ & 26.882 & $(17.618)$ & 21.233 & $(17.976)$ & 23.932 & (17.258) \\
\hline \multicolumn{7}{|l|}{ Ethnicity } \\
\hline White & -12.432 & (15.334) & -11.990 & (15.489) & -14.012 & (15.560) \\
\hline Black & -14.257 & (16.713) & -13.823 & (16.918) & -15.384 & (16.975) \\
\hline Latino & -2.734 & (7.618) & -2.590 & (7.836) & -1.968 & (7.864) \\
\hline Other & -4.511 & (17.154) & -5.844 & $(17.351)$ & -7.955 & (17.618) \\
\hline \multicolumn{7}{|l|}{ Other } \\
\hline Male & $31.826^{* * *}$ & $(4.800)$ & $30.983^{* * *}$ & $(4.856)$ & $29.676^{* * *}$ & $(4.791)$ \\
\hline $\mathrm{HH}$ members & 1.076 & (2.949) & 0.895 & (2.914) & 0.601 & (2.933) \\
\hline CC revolver & $-15.400^{* * *}$ & (5.098) & $-14.107^{* * *}$ & $(5.223)$ & $-11.953^{* *}$ & $(5.141)$ \\
\hline Home owner & $17.090^{* * *}$ & $(5.481)$ & $15.767^{* * *}$ & $(5.434)$ & $15.089^{* * *}$ & $(5.014)$ \\
\hline \multicolumn{7}{|l|}{ Rel. characteristics } \\
\hline Security & & & -0.734 & $(3.257)$ & -2.321 & $(3.222)$ \\
\hline Setup & & & -3.304 & (6.158) & -6.769 & $(6.106)$ \\
\hline Acceptance & & & 1.383 & $(9.081)$ & 0.816 & $(9.215)$ \\
\hline Costs & & & -8.711 & $(7.340)$ & -8.160 & (7.192) \\
\hline Records & & & 0.583 & $(4.814)$ & -1.448 & $(4.716)$ \\
\hline Convenience & & & $12.647^{*}$ & $(6.708)$ & $11.532^{*}$ & $(6.438)$ \\
\hline \multicolumn{7}{|l|}{ Withdrawal method } \\
\hline Bank teller & & & & & $20.921^{* * *}$ & $(7.011)$ \\
\hline Check casher & & & & & $93.853^{* *}$ & $(40.348)$ \\
\hline Cashback & & & & & $-13.221^{* *}$ & $(6.138)$ \\
\hline Employer & & & & & $36.721^{* *}$ & (15.692) \\
\hline Family & & & & & 4.369 & (10.858) \\
\hline Other & & & & & 28.434 & (19.534) \\
\hline Constant & $-175.522^{* * *}$ & $(49.091)$ & $-177.964^{* * *}$ & $(50.477)$ & $-206.167^{* * *}$ & (52.098) \\
\hline$R^{2}$ & 0.153 & & 0.155 & & 0.182 & \\
\hline Individuals & 1466 & & 1454 & & 1454 & \\
\hline
\end{tabular}

$b$ are the point estimates and se the standard errors. Cluster-robust standard errors and survey weights are used. $\mathrm{HH}$ and CC refers to household and credit card, respectively. Base category of categorical variables is lower than high school, unemployed, widowed, lower than 25 years, Asian, and ATM. Significance levels are denoted as ${ }^{* * *} p<0.01$, ${ }^{* *} p<0.05,{ }^{*} p<0.1$ 
Table 19 OLS regression results of contactless credit on cash share volume

\begin{tabular}{|c|c|c|c|c|c|c|}
\hline \multirow[b]{2}{*}{ Variable } & \multicolumn{2}{|l|}{ (1) } & \multicolumn{2}{|l|}{ (2) } & \multicolumn{2}{|l|}{ (3) } \\
\hline & $\mathbf{b}$ & se & $\mathbf{b}$ & se & $\mathbf{b}$ & se \\
\hline Contactless credit & $-0.053^{* *}$ & $(0.025)$ & $-0.052^{* *}$ & $(0.024)$ & $-0.059^{* *}$ & $(0.023)$ \\
\hline $\log ($ income) & -0.019 & $(0.012)$ & -0.009 & $(0.012)$ & -0.008 & $(0.011)$ \\
\hline Interest rate & $-0.041^{* * *}$ & $(0.016)$ & $-0.032^{* *}$ & $(0.013)$ & $-0.029^{* *}$ & $(0.012)$ \\
\hline \multicolumn{7}{|l|}{ Education } \\
\hline High school & -0.026 & $(0.073)$ & -0.062 & $(0.077)$ & -0.047 & $(0.071)$ \\
\hline Some college & -0.026 & $(0.071)$ & -0.062 & $(0.075)$ & -0.052 & $(0.070)$ \\
\hline College & -0.049 & $(0.071)$ & -0.076 & $(0.076)$ & -0.063 & $(0.070)$ \\
\hline Post graduate & -0.042 & $(0.071)$ & -0.080 & $(0.076)$ & -0.067 & $(0.072)$ \\
\hline \multicolumn{7}{|l|}{ Employment } \\
\hline Working & -0.012 & $(0.032)$ & -0.004 & $(0.031)$ & -0.013 & $(0.029)$ \\
\hline Retired & -0.059 & $(0.038)$ & -0.036 & $(0.035)$ & -0.047 & $(0.034)$ \\
\hline Other & 0.013 & $(0.030)$ & 0.021 & $(0.029)$ & 0.017 & $(0.028)$ \\
\hline \multicolumn{7}{|l|}{ Marital status } \\
\hline Single & $0.097^{*}$ & $(0.051)$ & $0.091^{*}$ & $(0.051)$ & $0.092^{* *}$ & $(0.044)$ \\
\hline Married & 0.059 & $(0.044)$ & 0.055 & $(0.044)$ & 0.049 & $(0.037)$ \\
\hline Separated & 0.037 & $(0.047)$ & 0.038 & $(0.047)$ & 0.040 & $(0.040)$ \\
\hline \multicolumn{7}{|l|}{ Age } \\
\hline $25-34$ & 0.042 & $(0.065)$ & 0.063 & $(0.065)$ & 0.064 & $(0.060)$ \\
\hline $35-44$ & 0.093 & $(0.067)$ & 0.099 & $(0.067)$ & $0.103^{*}$ & $(0.061)$ \\
\hline $45-54$ & $0.118^{*}$ & $(0.065)$ & $0.126^{*}$ & $(0.065)$ & $0.123^{* *}$ & $(0.060)$ \\
\hline $55-64$ & $0.144^{* *}$ & $(0.066)$ & $0.144^{* *}$ & $(0.066)$ & $0.143^{* *}$ & $(0.061)$ \\
\hline$>65$ & $0.185^{* * *}$ & $(0.072)$ & $0.177^{* *}$ & $(0.070)$ & $0.183^{* * *}$ & $(0.065)$ \\
\hline \multicolumn{7}{|l|}{ Ethnicity } \\
\hline White & -0.022 & $(0.066)$ & -0.046 & $(0.066)$ & -0.064 & $(0.064)$ \\
\hline Black & 0.017 & $(0.075)$ & -0.005 & $(0.074)$ & -0.021 & $(0.073)$ \\
\hline Latino & 0.008 & $(0.027)$ & 0.004 & $(0.027)$ & 0.008 & $(0.026)$ \\
\hline Other & 0.034 & $(0.081)$ & 0.014 & $(0.078)$ & -0.013 & $(0.077)$ \\
\hline \multicolumn{7}{|l|}{ Other } \\
\hline Male & $0.066^{* * *}$ & $(0.018)$ & $0.064^{* * *}$ & $(0.017)$ & $0.056^{* * *}$ & $(0.017)$ \\
\hline $\mathrm{HH}$ members & 0.002 & $(0.007)$ & 0.000 & $(0.007)$ & -0.001 & $(0.007)$ \\
\hline CC revolver & $-0.053^{* * *}$ & $(0.016)$ & $-0.053^{* * *}$ & $(0.015)$ & $-0.045^{* * *}$ & $(0.015)$ \\
\hline Home owner & $-0.058^{* * *}$ & $(0.020)$ & $-0.057^{* * *}$ & $(0.020)$ & $-0.059^{* * *}$ & $(0.019)$ \\
\hline \multicolumn{7}{|l|}{ Rel. characteristics } \\
\hline Security & & & -0.005 & $(0.011)$ & -0.008 & $(0.010)$ \\
\hline Setup & & & $0.043^{*}$ & $(0.022)$ & 0.032 & $(0.021)$ \\
\hline Acceptance & & & $-0.066^{* *}$ & $(0.033)$ & $-0.064^{* *}$ & $(0.031)$ \\
\hline Costs & & & $0.066^{* *}$ & $(0.026)$ & $0.061^{* *}$ & $(0.025)$ \\
\hline Records & & & 0.008 & $(0.016)$ & 0.004 & $(0.015)$ \\
\hline Convenience & & & $0.118^{* * *}$ & $(0.024)$ & $0.116^{* * *}$ & $(0.022)$ \\
\hline \multicolumn{7}{|l|}{ Withdrawal method } \\
\hline Bank teller & & & & & 0.027 & $(0.021)$ \\
\hline Check casher & & & & & 0.126 & $(0.170)$ \\
\hline Cashback & & & & & $-0.086^{* * *}$ & $(0.019)$ \\
\hline Employer & & & & & $0.209^{* * *}$ & $(0.078)$ \\
\hline Family & & & & & $-0.101^{*}$ & $(0.060)$ \\
\hline Other & & & & & $-0.088^{*}$ & $(0.046)$ \\
\hline Constant & $0.442^{* *}$ & $(0.189)$ & $0.499^{* * *}$ & $(0.190)$ & $0.497^{* * *}$ & $(0.171)$ \\
\hline$R^{2}$ & 0.083 & & 0.134 & & 0.173 & \\
\hline Individuals & 1475 & & 1463 & & 1463 & \\
\hline
\end{tabular}

$b$ are the point estimates and se the standard errors. Cluster-robust standard errors and survey weights are used. HH and CC refers to household and credit card, respectively. Base category of categorical variables is lower than high school, unemployed, widowed, lower than 25 years, Asian, and ATM. Significance levels are denoted as *** $p<0.01$, ${ }^{* *} p<0.05,{ }^{*} p<0.1$ 
Table 20 OLS regression results of contactless debit on cash share volume

\begin{tabular}{|c|c|c|c|c|c|c|}
\hline \multirow[b]{2}{*}{ Variable } & \multicolumn{2}{|l|}{$(1)$} & \multicolumn{2}{|l|}{ (2) } & \multicolumn{2}{|l|}{ (3) } \\
\hline & $\mathbf{b}$ & se & $\mathbf{b}$ & se & b & se \\
\hline Contactless debit & $-0.062^{* *}$ & $(0.026)$ & $-0.047^{*}$ & $(0.025)$ & $-0.043^{*}$ & $(0.024)$ \\
\hline log(income) & $-0.021^{*}$ & $(0.012)$ & -0.011 & $(0.012)$ & -0.011 & $(0.011)$ \\
\hline Interest rate & $-0.041^{* *}$ & $(0.016)$ & $-0.032^{* *}$ & $(0.013)$ & $-0.029^{* *}$ & $(0.012)$ \\
\hline \multicolumn{7}{|l|}{ Education } \\
\hline High school & -0.015 & $(0.071)$ & -0.048 & $(0.077)$ & -0.033 & $(0.072)$ \\
\hline Some college & -0.017 & $(0.069)$ & -0.050 & $(0.075)$ & -0.039 & $(0.070)$ \\
\hline College & -0.041 & $(0.070)$ & -0.066 & $(0.076)$ & -0.051 & $(0.071)$ \\
\hline Post graduate & -0.036 & $(0.070)$ & -0.071 & $(0.076)$ & -0.057 & $(0.072)$ \\
\hline \multicolumn{7}{|l|}{ Employment } \\
\hline Working & -0.011 & $(0.032)$ & -0.005 & $(0.030)$ & -0.015 & $(0.029)$ \\
\hline Retired & -0.057 & $(0.037)$ & -0.035 & $(0.035)$ & -0.045 & $(0.034)$ \\
\hline Other & 0.019 & $(0.029)$ & 0.025 & $(0.028)$ & 0.021 & $(0.027)$ \\
\hline \multicolumn{7}{|l|}{ Marital status } \\
\hline Single & $0.095^{*}$ & $(0.051)$ & $0.087^{*}$ & $(0.050)$ & $0.089^{* *}$ & $(0.044)$ \\
\hline Married & 0.060 & $(0.043)$ & 0.054 & $(0.044)$ & 0.049 & $(0.037)$ \\
\hline Separated & 0.037 & $(0.047)$ & 0.037 & $(0.047)$ & 0.039 & $(0.040)$ \\
\hline \multicolumn{7}{|l|}{ Age } \\
\hline $25-34$ & 0.047 & $(0.064)$ & 0.065 & $(0.065)$ & 0.066 & $(0.060)$ \\
\hline $35-44$ & 0.092 & $(0.067)$ & 0.097 & $(0.067)$ & 0.101 & $(0.062)$ \\
\hline $45-54$ & $0.117^{*}$ & $(0.065)$ & $0.124^{*}$ & $(0.065)$ & $0.123^{* *}$ & $(0.061)$ \\
\hline $55-64$ & $0.143^{* *}$ & $(0.066)$ & $0.143^{* *}$ & $(0.066)$ & $0.143^{* *}$ & $(0.062)$ \\
\hline$>65$ & $0.183^{* *}$ & $(0.072)$ & $0.173^{* *}$ & $(0.071)$ & $0.180^{* * *}$ & $(0.067)$ \\
\hline \multicolumn{7}{|l|}{ Ethnicity } \\
\hline White & -0.020 & $(0.066)$ & -0.043 & $(0.066)$ & -0.060 & $(0.065)$ \\
\hline Black & 0.030 & $(0.074)$ & 0.007 & $(0.074)$ & -0.008 & $(0.073)$ \\
\hline Latino & 0.009 & $(0.027)$ & 0.005 & $(0.027)$ & 0.008 & $(0.026)$ \\
\hline Other & 0.042 & $(0.080)$ & 0.020 & $(0.078)$ & -0.006 & $(0.077)$ \\
\hline \multicolumn{7}{|l|}{ Other } \\
\hline Male & $0.066^{* * *}$ & $(0.018)$ & $0.064^{* * *}$ & $(0.017)$ & $0.056^{* * *}$ & $(0.017)$ \\
\hline $\mathrm{HH}$ members & 0.003 & $(0.007)$ & 0.001 & $(0.007)$ & -0.001 & $(0.007)$ \\
\hline CC revolver & $-0.054^{* * *}$ & $(0.016)$ & $-0.054^{* * *}$ & $(0.015)$ & $-0.046^{* * *}$ & $(0.015)$ \\
\hline Home owner & $-0.059^{* * *}$ & $(0.020)$ & $-0.057^{* * *}$ & $(0.020)$ & $-0.059^{* * *}$ & $(0.020)$ \\
\hline \multicolumn{7}{|l|}{ Rel. characteristics } \\
\hline Security & & & -0.003 & $(0.011)$ & -0.006 & $(0.010)$ \\
\hline Setup & & & $0.038^{*}$ & $(0.022)$ & 0.027 & $(0.022)$ \\
\hline Acceptance & & & $-0.065^{* *}$ & $(0.033)$ & $-0.063^{* *}$ & $(0.031)$ \\
\hline Costs & & & $0.071^{* * *}$ & $(0.027)$ & $0.066^{* * *}$ & $(0.026)$ \\
\hline Records & & & 0.008 & $(0.016)$ & 0.004 & $(0.015)$ \\
\hline Convenience & & & $0.115^{* * *}$ & $(0.024)$ & $0.113^{* * *}$ & $(0.022)$ \\
\hline \multicolumn{7}{|l|}{ Withdrawal method } \\
\hline Bank teller & & & & & 0.024 & $(0.021)$ \\
\hline Check casher & & & & & 0.129 & $(0.170)$ \\
\hline Cashback & & & & & $-0.083^{* * *}$ & (0.019) \\
\hline Employer & & & & & $0.210^{* * *}$ & $(0.077)$ \\
\hline Family & & & & & -0.097 & $(0.060)$ \\
\hline Other & & & & & $-0.087^{*}$ & $(0.046)$ \\
\hline Constant & $0.455^{* *}$ & $(0.191)$ & $0.507^{* * *}$ & $(0.191)$ & $0.503^{* * *}$ & $(0.173)$ \\
\hline$R^{2}$ & 0.084 & & 0.132 & & 0.170 & \\
\hline Individuals & 1476 & & 1464 & & 1464 & \\
\hline
\end{tabular}

$b$ are the point estimates and se the standard errors. Cluster-robust standard errors and survey weights are used. $\mathrm{HH}$ and CC refers to household and credit card, respectively. Base category of categorical variables is lower than high school, unemployed, widowed, lower than 25 years, Asian, and ATM. Significance levels are denoted as ${ }^{* * *} p<0.01$, ${ }^{* *} p<0.05,{ }^{*} p<0.1$ 
Table 21 FE regression results of contactless credit on usual cash withdrawn

\begin{tabular}{|c|c|c|c|c|c|c|}
\hline \multirow[b]{2}{*}{ Variable } & \multicolumn{2}{|l|}{ (1) } & \multicolumn{2}{|l|}{ (2) } & \multicolumn{2}{|l|}{ (3) } \\
\hline & b & se & b & se & b & se \\
\hline Contactless credit & 6.766 & (8.994) & 6.855 & $(11.044)$ & 8.906 & $(9.824)$ \\
\hline $\log ($ income) & $14.122^{* *}$ & $(5.529)$ & $13.766^{* *}$ & (6.516) & $13.252^{* *}$ & $(6.046)$ \\
\hline Interest rate & -7.159 & $(4.711)$ & -6.441 & $(6.039)$ & -7.647 & $(5.589)$ \\
\hline \multicolumn{7}{|l|}{ Education } \\
\hline High school & $43.406^{* * *}$ & $(14.167)$ & $122.086^{* * *}$ & (14.509) & $85.841^{* * *}$ & $(15.074)$ \\
\hline Some college & 32.472 & $(34.641)$ & $89.550^{* *}$ & (38.303) & $54.721^{*}$ & (33.044) \\
\hline College & 12.856 & $(40.084)$ & $77.117^{*}$ & $(44.403)$ & 48.044 & $(37.261)$ \\
\hline Post graduate & 108.020 & (96.184) & 158.726 & $(114.876)$ & 129.450 & (103.538) \\
\hline \multicolumn{7}{|l|}{ Employment } \\
\hline Working & 0.219 & $(7.063)$ & 1.280 & (8.799) & -6.703 & $(8.585)$ \\
\hline Retired & $16.541^{*}$ & $(9.485)$ & 2.175 & $(15.467)$ & 2.803 & $(12.956)$ \\
\hline Other & 11.452 & (9.673) & -5.453 & $(11.630)$ & -2.332 & (9.974) \\
\hline \multicolumn{7}{|l|}{ Marital status } \\
\hline Single & -13.859 & $(26.602)$ & 23.607 & (20.204) & 19.462 & $(16.548)$ \\
\hline Married & -32.397 & $(24.074)$ & -4.865 & $(12.767)$ & -1.174 & (10.759) \\
\hline Separated & $-64.106^{* *}$ & $(32.425)$ & -39.145 & (27.394) & -32.862 & $(26.563)$ \\
\hline \multicolumn{7}{|l|}{ Age } \\
\hline $25-34$ & -2.776 & $(24.980)$ & -54.813 & $(50.620)$ & -42.631 & $(31.037)$ \\
\hline $35-44$ & 7.863 & (31.520) & -43.913 & $(56.847)$ & -30.950 & (38.648) \\
\hline $45-54$ & 30.710 & (33.577) & -29.556 & $(58.464)$ & -20.446 & $(40.516)$ \\
\hline $55-64$ & 22.564 & $(36.222)$ & -54.677 & $(60.666)$ & -43.059 & $(43.378)$ \\
\hline$>65$ & 22.965 & (38.734) & -63.749 & $(63.070)$ & -54.154 & $(46.441)$ \\
\hline \multicolumn{7}{|l|}{ Other } \\
\hline $\mathrm{HH}$ members & 1.347 & $(4.757)$ & -0.497 & $(5.104)$ & -0.563 & $(4.871)$ \\
\hline CC revolver & -8.449 & $(5.819)$ & -7.186 & $(7.256)$ & -4.161 & $(6.674)$ \\
\hline Home owner & -0.779 & $(10.929)$ & -6.971 & (13.889) & -6.730 & $(13.816)$ \\
\hline \multicolumn{7}{|l|}{ Rel. characteristics } \\
\hline Security & & & -4.807 & (3.289) & -4.943 & $(3.177)$ \\
\hline Setup & & & $11.827^{* *}$ & $(5.155)$ & 6.380 & $(5.042)$ \\
\hline Acceptance & & & 2.090 & $(9.564)$ & 2.860 & $(8.746)$ \\
\hline Costs & & & -4.646 & $(7.541)$ & -6.628 & $(7.101)$ \\
\hline Records & & & -6.953 & $(5.380)$ & -4.379 & $(4.876)$ \\
\hline Convenience & & & -4.244 & $(7.456)$ & -3.704 & $(7.332)$ \\
\hline \multicolumn{7}{|l|}{ Withdrawal method } \\
\hline Bank teller & & & & & $59.979 * * *$ & (11.149) \\
\hline Check casher & & & & & $167.391^{* * *}$ & $(56.741)$ \\
\hline Cashback & & & & & $-32.326^{* * *}$ & $(7.362)$ \\
\hline Employer & & & & & $96.928^{* *}$ & $(42.046)$ \\
\hline Family & & & & & -19.688 & (19.508) \\
\hline Other & & & & & $93.385^{* * *}$ & $(27.951)$ \\
\hline Constant & -68.904 & (73.526) & -84.921 & $(93.207)$ & -74.108 & $(80.500)$ \\
\hline$R^{2}$ & 0.012 & & 0.016 & & 0.088 & \\
\hline Observations & 3592 & & 2865 & & 2865 & \\
\hline Individuals & 853 & & 845 & & 845 & \\
\hline
\end{tabular}

FE is the fixed-effects estimator obtained on the balanced panel. $b$ are the point estimates and se the standard errors. Cluster-robust standard errors are used. HH and CC refers to household and credit card, respectively. Base category of categorical variables is lower than high school, unemployed, widowed, lower than 25 years, Asian, and ATM. Significance levels are denoted as ${ }^{* * *} p<0.01,{ }^{* *} p<0.05,{ }^{*} p<0.1$ 
Table 22 FE regression results of contactless debit on usual cash withdrawn

\begin{tabular}{|c|c|c|c|c|c|c|}
\hline \multirow[b]{2}{*}{ Variable } & \multicolumn{2}{|l|}{ (1) } & \multicolumn{2}{|l|}{ (2) } & \multicolumn{2}{|l|}{ (3) } \\
\hline & b & se & b & se & b & se \\
\hline Contactless debit & -2.250 & (7.691) & -2.966 & $(7.751)$ & -5.062 & $(7.725)$ \\
\hline $\log ($ income) & $13.180^{* * *}$ & $(5.052)$ & $14.032^{* *}$ & $(6.080)$ & $14.064^{* *}$ & $(5.722)$ \\
\hline Interest rate & -6.115 & (4.419) & -5.534 & (5.620) & -5.703 & (5.316) \\
\hline \multicolumn{7}{|l|}{ Education } \\
\hline High school & $43.297^{* * *}$ & $(16.342)$ & $110.610^{* * *}$ & (14.186) & $73.845^{* * *}$ & $(15.433)$ \\
\hline Some college & $79.346^{* * *}$ & (23.743) & $177.691^{* * *}$ & $(57.411)$ & $89.593^{*}$ & (47.979) \\
\hline College & 50.543 & $(31.071)$ & $153.333^{* *}$ & $(60.971)$ & 71.590 & $(51.456)$ \\
\hline Post graduate & $134.919^{*}$ & (81.733) & $239.194^{* *}$ & (120.869) & 154.730 & (109.015) \\
\hline \multicolumn{7}{|l|}{ Employment } \\
\hline Working & -2.741 & (7.396) & -4.863 & (8.944) & -9.299 & (8.963) \\
\hline Retired & $19.282^{*}$ & $(10.956)$ & 5.419 & (15.423) & 5.857 & (13.374) \\
\hline Other & 8.306 & (8.753) & -6.275 & (11.157) & -5.310 & (9.909) \\
\hline \multicolumn{7}{|l|}{ Marital status } \\
\hline Single & -16.405 & (25.948) & 15.137 & $(18.551)$ & 15.823 & (16.334) \\
\hline Married & -35.387 & (23.518) & -9.051 & (12.606) & -3.195 & $(10.892)$ \\
\hline Separated & $-58.642^{*}$ & (30.508) & -30.496 & (23.113) & -21.275 & $(22.700)$ \\
\hline \multicolumn{7}{|l|}{ Age } \\
\hline $25-34$ & $27.552^{*}$ & (15.736) & -2.481 & (9.766) & 0.370 & $(12.142)$ \\
\hline $35-44$ & $45.886^{*}$ & (23.834) & 15.797 & (28.556) & 21.034 & (26.914) \\
\hline $45-54$ & $65.007^{* *}$ & $(26.469)$ & 26.038 & $(31.001)$ & 26.697 & $(29.051)$ \\
\hline $55-64$ & $63.898^{* *}$ & (29.855) & 12.884 & (35.174) & 15.375 & (33.524) \\
\hline$>65$ & $71.227^{* *}$ & $(32.871)$ & 4.624 & $(37.857)$ & 5.884 & (36.258) \\
\hline \multicolumn{7}{|l|}{ Other } \\
\hline $\mathrm{HH}$ members & -0.524 & $(4.680)$ & -0.951 & (4.890) & -0.696 & $(4.738)$ \\
\hline CC revolver & -7.442 & $(5.676)$ & -3.239 & $(6.892)$ & -1.042 & (6.369) \\
\hline Home owner & -6.778 & $(10.660)$ & -17.967 & (13.238) & -17.593 & $(13.200)$ \\
\hline \multicolumn{7}{|l|}{ Rel. characteristics } \\
\hline Security & & & -5.028 & (3.208) & -4.280 & (3.126) \\
\hline Setup & & & $10.431^{* *}$ & (4.616) & 7.110 & $(4.588)$ \\
\hline Acceptance & & & 3.481 & (8.858) & 4.735 & (8.138) \\
\hline Costs & & & 1.605 & (7.332) & 0.797 & (6.999) \\
\hline Records & & & -1.113 & $(5.140)$ & -0.076 & $(4.793)$ \\
\hline Convenience & & & -4.070 & $(6.906)$ & -4.625 & $(6.730)$ \\
\hline \multicolumn{7}{|l|}{ Withdrawal method } \\
\hline Bank teller & & & & & $55.641^{* * *}$ & $(10.210)$ \\
\hline Check casher & & & & & $137.978^{* *}$ & $(67.915)$ \\
\hline Cashback & & & & & $-26.767^{* * *}$ & $(6.760)$ \\
\hline Employer & & & & & 67.020 & $(43.680)$ \\
\hline Family & & & & & -11.546 & $(19.602)$ \\
\hline Other & & & & & $95.660^{* * *}$ & (28.368) \\
\hline Constant & $-118.698^{*}$ & $(67.890)$ & $-187.422^{* *}$ & $(92.827)$ & -134.658 & (83.228) \\
\hline$R^{2}$ & 0.012 & & 0.011 & & 0.067 & \\
\hline Observations & 3874 & & 3084 & & 3084 & \\
\hline Individuals & 906 & & 899 & & 899 & \\
\hline
\end{tabular}

FE is the fixed-effects estimator obtained on the balanced panel. $b$ are the point estimates and se the standard errors. Cluster-robust standard errors are used. $\mathrm{HH}$ and $\mathrm{CC}$ refers to household and credit card, respectively. Base category of categorical variables is lower than high school, unemployed, widowed, lower than 25 years, Asian, and ATM. Significance levels are denoted as ${ }^{* *} p<0.01,{ }^{* *} p<0.05,{ }^{*} p<0.1$ 
Table 23 FE regression results of contactless credit on number of withdrawals

\begin{tabular}{|c|c|c|c|c|c|c|}
\hline \multirow[b]{2}{*}{ Variable } & \multicolumn{2}{|l|}{ (1) } & \multicolumn{2}{|l|}{ (2) } & \multicolumn{2}{|l|}{ (3) } \\
\hline & $\mathbf{b}$ & se & $\mathbf{b}$ & se & $\mathbf{b}$ & se \\
\hline Contactless credit & -0.325 & $(0.355)$ & -0.326 & $(0.435)$ & -0.295 & $(0.446)$ \\
\hline $\log ($ income) & $0.290^{*}$ & $(0.152)$ & 0.193 & $(0.198)$ & 0.236 & $(0.196)$ \\
\hline Interest rate & 0.203 & $(0.131)$ & 0.282 & $(0.184)$ & 0.237 & $(0.184)$ \\
\hline \multicolumn{7}{|l|}{ Education } \\
\hline High school & $1.449^{* * *}$ & $(0.391)$ & $1.490^{* * *}$ & $(0.354)$ & $1.996^{* * *}$ & $(0.382)$ \\
\hline Some college & 1.229 & (1.358) & 1.101 & $(1.889)$ & 1.803 & $(2.043)$ \\
\hline College & 1.800 & $(1.601)$ & 1.751 & $(2.139)$ & 2.333 & $(2.274)$ \\
\hline Post graduate & 1.793 & $(1.497)$ & 1.699 & $(2.123)$ & 2.274 & $(2.254)$ \\
\hline \multicolumn{7}{|l|}{ Employment } \\
\hline Working & -0.058 & $(0.292)$ & 0.199 & $(0.364)$ & 0.236 & $(0.354)$ \\
\hline Retired & -0.031 & $(0.415)$ & -0.040 & $(0.742)$ & 0.096 & $(0.742)$ \\
\hline Other & -0.008 & $(0.315)$ & 0.237 & $(0.474)$ & 0.170 & $(0.469)$ \\
\hline \multicolumn{7}{|l|}{ Marital status } \\
\hline Single & -0.645 & $(0.711)$ & 0.060 & $(0.843)$ & 0.035 & $(0.791)$ \\
\hline Married & -0.838 & $(0.577)$ & -0.772 & $(0.600)$ & -0.780 & $(0.571)$ \\
\hline Separated & -0.951 & $(0.782)$ & -0.952 & $(0.831)$ & -0.907 & $(0.812)$ \\
\hline \multicolumn{7}{|l|}{ Age } \\
\hline $25-34$ & 0.826 & $(0.538)$ & 0.618 & (1.199) & 0.551 & $(1.097)$ \\
\hline $35-44$ & $1.439^{* *}$ & $(0.653)$ & 1.504 & $(1.261)$ & 1.458 & (1.149) \\
\hline $45-54$ & $1.691^{* *}$ & $(0.752)$ & 1.615 & $(1.357)$ & 1.558 & $(1.242)$ \\
\hline $55-64$ & $1.688^{* *}$ & $(0.783)$ & 1.465 & $(1.394)$ & 1.321 & $(1.280)$ \\
\hline$>65$ & 1.290 & $(0.862)$ & 0.999 & $(1.473)$ & 0.736 & (1.359) \\
\hline \multicolumn{7}{|l|}{ Other } \\
\hline $\mathrm{HH}$ members & 0.007 & $(0.091)$ & 0.090 & $(0.118)$ & 0.063 & $(0.115)$ \\
\hline CC revolver & 0.136 & $(0.231)$ & -0.117 & $(0.262)$ & -0.151 & $(0.255)$ \\
\hline Home owner & 0.059 & $(0.418)$ & 0.260 & $(0.507)$ & 0.259 & $(0.498)$ \\
\hline \multicolumn{7}{|l|}{ Rel. characteristics } \\
\hline Security & & & 0.022 & $(0.088)$ & -0.005 & $(0.088)$ \\
\hline Setup & & & -0.057 & $(0.220)$ & -0.076 & $(0.219)$ \\
\hline Acceptance & & & -0.322 & $(0.266)$ & -0.294 & $(0.257)$ \\
\hline Costs & & & 0.074 & $(0.187)$ & 0.074 & $(0.186)$ \\
\hline Records & & & 0.033 & $(0.138)$ & -0.010 & $(0.134)$ \\
\hline Convenience & & & -0.034 & $(0.163)$ & -0.024 & $(0.162)$ \\
\hline \multicolumn{7}{|l|}{ Withdrawal method } \\
\hline Bank teller & & & & & $-0.657^{* * *}$ & $(0.223)$ \\
\hline Check casher & & & & & -1.107 & $(0.828)$ \\
\hline Cashback & & & & & 0.353 & $(0.299)$ \\
\hline Employer & & & & & 1.245 & $(0.937)$ \\
\hline Family & & & & & 0.391 & $(0.459)$ \\
\hline Other & & & & & $1.723^{* * *}$ & $(0.576)$ \\
\hline Constant & -2.080 & (2.134) & -1.437 & (2.954) & -2.437 & (2.952) \\
\hline$R^{2}$ & 0.006 & & 0.009 & & 0.031 & \\
\hline Observations & 3602 & & 2874 & & 2873 & \\
\hline Individuals & 853 & & 847 & & 846 & \\
\hline
\end{tabular}

FE is the fixed-effects estimator obtained on the balanced panel. $b$ are the point estimates and se the standard errors. Cluster-robust standard errors are used. $\mathrm{HH}$ and $\mathrm{CC}$ refers to household and credit card, respectively. Base category of categorical variables is lower than high school, unemployed, widowed, lower than 25 years, Asian, and ATM. Significance levels are denoted as ${ }^{* *} p<0.01,{ }^{* *} p<0.05,{ }^{*} p<0.1$ 
Table 24 FE regression results of contactless debit on number of withdrawals

\begin{tabular}{|c|c|c|c|c|c|c|}
\hline \multirow[b]{2}{*}{ Variable } & \multicolumn{2}{|l|}{ (1) } & \multicolumn{2}{|l|}{ (2) } & \multicolumn{2}{|l|}{ (3) } \\
\hline & b & se & b & se & b & se \\
\hline Contactless debit & $-0.904^{*}$ & $(0.502)$ & -0.942 & $(0.634)$ & -0.941 & $(0.625)$ \\
\hline $\log ($ income) & 0.186 & $(0.131)$ & 0.151 & $(0.186)$ & 0.179 & $(0.185)$ \\
\hline Interest rate & 0.180 & $(0.119)$ & 0.195 & $(0.164)$ & 0.171 & $(0.165)$ \\
\hline \multicolumn{7}{|l|}{ Education } \\
\hline High school & $1.397^{* * *}$ & $(0.281)$ & $1.366^{* * *}$ & $(0.319)$ & $1.794^{* * *}$ & $(0.345)$ \\
\hline Some college & 1.176 & $(1.763)$ & -5.620 & $(5.910)$ & -5.640 & $(6.675)$ \\
\hline College & 2.032 & $(1.993)$ & -4.699 & $(6.010)$ & -4.814 & $(6.763)$ \\
\hline Post graduate & 2.141 & (1.893) & -4.665 & $(6.004)$ & -4.771 & $(6.758)$ \\
\hline \multicolumn{7}{|l|}{ Employment } \\
\hline Working & -0.171 & $(0.258)$ & 0.112 & $(0.322)$ & 0.096 & $(0.310)$ \\
\hline Retired & -0.442 & $(0.322)$ & -0.378 & $(0.616)$ & -0.231 & $(0.605)$ \\
\hline Other & -0.149 & $(0.215)$ & -0.178 & $(0.312)$ & -0.246 & $(0.310)$ \\
\hline \multicolumn{7}{|l|}{ Marital status } \\
\hline Single & -0.182 & $(0.864)$ & 0.729 & $(1.050)$ & 0.685 & $(1.027)$ \\
\hline Married & -0.925 & $(0.578)$ & -0.718 & $(0.591)$ & -0.725 & $(0.562)$ \\
\hline Separated & -1.370 & $(0.845)$ & -1.189 & $(0.922)$ & -1.201 & (0.909) \\
\hline \multicolumn{7}{|l|}{ Age } \\
\hline $25-34$ & 0.377 & $(0.443)$ & -0.167 & $(0.892)$ & -0.220 & $(0.916)$ \\
\hline $35-44$ & 0.675 & $(0.567)$ & 0.491 & $(0.947)$ & 0.490 & $(0.948)$ \\
\hline $45-54$ & 0.880 & $(0.687)$ & 0.472 & $(1.085)$ & 0.444 & $(1.075)$ \\
\hline $55-64$ & 0.779 & $(0.743)$ & 0.408 & $(1.155)$ & 0.337 & $(1.145)$ \\
\hline$>65$ & 0.612 & $(0.841)$ & 0.215 & $(1.268)$ & 0.033 & $(1.255)$ \\
\hline \multicolumn{7}{|l|}{ Other } \\
\hline $\mathrm{HH}$ members & 0.074 & $(0.093)$ & 0.125 & $(0.116)$ & 0.108 & $(0.113)$ \\
\hline CC revolver & 0.127 & $(0.199)$ & -0.033 & $(0.249)$ & -0.054 & $(0.244)$ \\
\hline Home owner & -0.034 & $(0.391)$ & 0.040 & $(0.472)$ & 0.048 & $(0.461)$ \\
\hline \multicolumn{7}{|l|}{ Rel. characteristics } \\
\hline Security & & & 0.054 & $(0.084)$ & 0.027 & $(0.083)$ \\
\hline Setup & & & -0.056 & $(0.191)$ & -0.086 & $(0.189)$ \\
\hline Acceptance & & & -0.168 & $(0.224)$ & -0.140 & $(0.212)$ \\
\hline Costs & & & 0.098 & $(0.168)$ & 0.103 & $(0.166)$ \\
\hline Records & & & 0.098 & $(0.128)$ & 0.060 & $(0.126)$ \\
\hline Convenience & & & 0.118 & $(0.128)$ & 0.112 & $(0.126)$ \\
\hline \multicolumn{7}{|l|}{ Withdrawal method } \\
\hline Bank teller & & & & & $-0.550^{* *}$ & $(0.215)$ \\
\hline Check casher & & & & & -0.631 & $(0.392)$ \\
\hline Cashback & & & & & 0.276 & $(0.302)$ \\
\hline Employer & & & & & $1.804^{*}$ & $(0.964)$ \\
\hline Family & & & & & 0.017 & $(0.448)$ \\
\hline Other & & & & & $1.824^{* * *}$ & $(0.566)$ \\
\hline Constant & -0.233 & $(2.324)$ & 5.909 & $(5.481)$ & 5.619 & (6.049) \\
\hline$R^{2}$ & 0.008 & & 0.015 & & 0.041 & \\
\hline Observations & 3882 & & 3090 & & 3089 & \\
\hline Individuals & 906 & & 900 & & 899 & \\
\hline
\end{tabular}

FE is the fixed-effects estimator obtained on the balanced panel. $b$ are the point estimates and se the standard errors. Cluster-robust standard errors are used. $\mathrm{HH}$ and $\mathrm{CC}$ refers to household and credit card, respectively. Base category of categorical variables is lower than high school, unemployed, widowed, lower than 25 years, Asian, and ATM. Significance levels are denoted as ${ }^{* *} p<0.01,{ }^{* *} p<0.05,{ }^{*} p<0.1$ 
Table 25 FE regression results of contactless credit on cash in wallet

\begin{tabular}{|c|c|c|c|c|c|c|}
\hline \multirow[b]{2}{*}{ Variable } & \multicolumn{2}{|l|}{$(1)$} & \multicolumn{2}{|l|}{ (2) } & \multicolumn{2}{|l|}{ (3) } \\
\hline & $\mathbf{b}$ & se & $\mathbf{b}$ & se & $\mathbf{b}$ & se \\
\hline Contactless credit & 8.371 & $(12.976)$ & 6.850 & $(14.477)$ & 6.067 & $(14.318)$ \\
\hline $\log ($ income) & $12.786^{* * *}$ & $(4.315)$ & $11.055^{* * *}$ & $(4.237)$ & $10.827^{* *}$ & $(4.272)$ \\
\hline Interest rate & -4.682 & $(4.328)$ & -7.248 & $(5.624)$ & -6.786 & $(5.622)$ \\
\hline \multicolumn{7}{|l|}{ Education } \\
\hline High school & $22.749^{* * *}$ & $(6.643)$ & $21.033^{* *}$ & $(9.831)$ & 5.685 & (10.927) \\
\hline Some college & 34.216 & $(22.420)$ & 37.017 & $(28.817)$ & 18.492 & (27.996) \\
\hline College & $56.729^{* *}$ & $(27.883)$ & $57.559^{*}$ & (34.903) & 40.469 & (34.991) \\
\hline Post graduate & $90.759^{* *}$ & $(42.140)$ & 69.550 & $(42.755)$ & 49.777 & $(41.246)$ \\
\hline \multicolumn{7}{|l|}{ Employment } \\
\hline Working & -5.712 & $(7.804)$ & -3.206 & $(8.858)$ & -3.256 & (8.653) \\
\hline Retired & 5.639 & (9.589) & $33.880^{* * *}$ & $(12.537)$ & $33.505^{* * *}$ & (12.363) \\
\hline Other & 8.499 & $(8.777)$ & 0.718 & $(10.640)$ & 1.618 & (10.546) \\
\hline \multicolumn{7}{|l|}{ Marital status } \\
\hline Single & 3.580 & $(25.940)$ & 31.442 & (38.132) & 30.960 & (37.818) \\
\hline Married & -2.111 & $(24.427)$ & 10.350 & $(36.163)$ & 11.797 & (35.912) \\
\hline Separated & 0.832 & $(24.022)$ & 6.940 & (35.086) & 7.005 & (34.823) \\
\hline \multicolumn{7}{|l|}{ Age } \\
\hline $25-34$ & -12.806 & $(14.095)$ & $-47.290^{*}$ & $(24.754)$ & $-48.077^{*}$ & $(26.045)$ \\
\hline $35-44$ & -9.874 & $(18.077)$ & -39.249 & $(27.810)$ & -40.680 & $(28.671)$ \\
\hline $45-54$ & -11.948 & $(19.972)$ & -43.834 & $(30.011)$ & -43.679 & (30.794) \\
\hline $55-64$ & -0.598 & $(21.883)$ & -31.003 & $(32.207)$ & -30.349 & (32.904) \\
\hline$>65$ & 2.505 & $(23.721)$ & -27.453 & (33.924) & -25.689 & (34.512) \\
\hline \multicolumn{7}{|l|}{ Other } \\
\hline $\mathrm{HH}$ members & 0.613 & $(2.484)$ & -0.103 & $(3.061)$ & 0.088 & (3.078) \\
\hline CC revolver & -0.053 & $(4.976)$ & -1.117 & $(6.277)$ & -1.473 & (6.354) \\
\hline Home owner & -2.163 & (8.108) & -6.272 & $(10.283)$ & -6.916 & $(10.301)$ \\
\hline \multicolumn{7}{|l|}{ Rel. characteristics } \\
\hline Security & & & -2.873 & $(2.274)$ & -2.415 & $(2.262)$ \\
\hline Setup & & & 2.135 & $(4.750)$ & 2.088 & $(4.763)$ \\
\hline Acceptance & & & -0.195 & $(5.424)$ & -0.452 & $(5.493)$ \\
\hline Costs & & & -1.493 & $(5.273)$ & -1.690 & $(5.286)$ \\
\hline Records & & & 3.188 & (3.449) & 3.792 & $(3.452)$ \\
\hline Convenience & & & -1.924 & $(4.760)$ & -1.777 & $(4.800)$ \\
\hline \multicolumn{7}{|l|}{ Withdrawal method } \\
\hline Bank teller & & & & & $21.945^{* * *}$ & (7.388) \\
\hline Check casher & & & & & 6.857 & (13.532) \\
\hline Cashback & & & & & -0.751 & (4.903) \\
\hline Employer & & & & & -18.784 & (15.614) \\
\hline Family & & & & & 12.484 & (9.592) \\
\hline Other & & & & & 5.559 & (13.758) \\
\hline Constant & $-111.279^{* *}$ & $(55.791)$ & -72.804 & (66.349) & -58.150 & (66.991) \\
\hline$R^{2}$ & 0.009 & & 0.014 & & 0.024 & \\
\hline Observations & 3599 & & 2874 & & 2874 & \\
\hline Individuals & 851 & & 844 & & 844 & \\
\hline
\end{tabular}

$\mathrm{FE}$ is the fixed-effects estimator obtained on the balanced panel. $b$ are the point estimates and se the standard errors. Cluster-robust standard errors are used. $\mathrm{HH}$ and $\mathrm{CC}$ refers to household and credit card, respectively. Base category of categorical variables is lower than high school, unemployed, widowed, lower than 25 years, Asian, and ATM. Significance levels are denoted as ${ }^{* * *} p<0.01,{ }^{* *} p<0.05,{ }^{*} p<0.1$ 
Table 26 FE regression results of contactless debit on cash in wallet

\begin{tabular}{|c|c|c|c|c|c|c|}
\hline \multirow[b]{2}{*}{ Variable } & \multicolumn{2}{|l|}{ (1) } & \multicolumn{2}{|l|}{ (2) } & \multicolumn{2}{|l|}{ (3) } \\
\hline & b & se & $\mathbf{b}$ & se & b & se \\
\hline Contactless debit & 3.789 & $(5.966)$ & 4.256 & $(7.965)$ & 3.206 & $(7.945)$ \\
\hline $\log ($ income) & $14.059^{* * *}$ & $(5.240)$ & $13.057^{* * *}$ & (4.988) & $13.154^{* * *}$ & $(5.006)$ \\
\hline Interest rate & -3.960 & $(4.175)$ & -7.424 & (5.338) & -7.002 & (5.358) \\
\hline \multicolumn{7}{|l|}{ Education } \\
\hline High school & $22.962^{* * *}$ & $(5.741)$ & $23.694^{* *}$ & $(9.272)$ & 13.458 & (10.292) \\
\hline Some college & 8.841 & $(40.354)$ & -42.988 & $(49.328)$ & -46.158 & (35.830) \\
\hline College & 33.112 & $(43.942)$ & -25.073 & $(52.826)$ & -27.669 & (40.513) \\
\hline Post graduate & 60.546 & $(52.828)$ & -16.242 & $(58.945)$ & -20.329 & $(47.134)$ \\
\hline \multicolumn{7}{|l|}{ Employment } \\
\hline Working & 2.339 & $(7.593)$ & 4.849 & (8.873) & 5.420 & $(8.717)$ \\
\hline Retired & 6.492 & (8.506) & $25.442^{* *}$ & $(12.730)$ & $24.980^{* *}$ & (12.509) \\
\hline Other & 7.170 & $(7.620)$ & 4.548 & (9.582) & 5.150 & (9.593) \\
\hline \multicolumn{7}{|l|}{ Marital status } \\
\hline Single & -5.355 & $(21.662)$ & 3.977 & (32.038) & 4.851 & (31.983) \\
\hline Married & -17.728 & (20.232) & -11.518 & (30.069) & -9.448 & (29.966) \\
\hline Separated & -25.935 & (24.999) & -29.421 & (36.135) & -26.059 & (35.745) \\
\hline \multicolumn{7}{|l|}{ Age } \\
\hline $25-34$ & 5.047 & $(13.856)$ & -33.830 & $(26.245)$ & -31.345 & (26.809) \\
\hline $35-44$ & 4.502 & (17.233) & -32.614 & (29.194) & -31.246 & (29.329) \\
\hline $45-54$ & 2.512 & $(19.327)$ & -40.682 & $(31.522)$ & -37.907 & (31.710) \\
\hline $55-64$ & 17.968 & $(21.568)$ & -24.783 & $(33.801)$ & -21.768 & (33.750) \\
\hline$>65$ & 25.009 & $(23.794)$ & -17.044 & (35.696) & -13.001 & (35.650) \\
\hline \multicolumn{7}{|l|}{ Other } \\
\hline $\mathrm{HH}$ members & -0.748 & $(2.545)$ & -0.673 & (3.064) & -0.704 & (3.049) \\
\hline CC revolver & -3.961 & $(4.785)$ & -1.643 & $(5.826)$ & -1.743 & $(5.844)$ \\
\hline Home owner & -1.334 & $(7.684)$ & -7.772 & $(9.411)$ & -8.442 & $(9.467)$ \\
\hline \multicolumn{7}{|l|}{ Rel. characteristics } \\
\hline Security & & & -3.354 & $(2.297)$ & -3.030 & $(2.304)$ \\
\hline Setup & & & 3.689 & $(4.183)$ & 3.683 & $(4.189)$ \\
\hline Acceptance & & & -0.064 & (4.609) & -0.270 & $(4.640)$ \\
\hline Costs & & & -2.416 & (4.978) & -2.466 & $(4.982)$ \\
\hline Records & & & 1.844 & (3.087) & 2.089 & (3.093) \\
\hline Convenience & & & -3.301 & $(4.358)$ & -3.054 & $(4.361)$ \\
\hline \multicolumn{7}{|l|}{ Withdrawal method } \\
\hline Bank teller & & & & & $14.425^{* *}$ & $(6.723)$ \\
\hline Check casher & & & & & 4.667 & (13.153) \\
\hline Cashback & & & & & -3.940 & $(5.414)$ \\
\hline Employer & & & & & -17.593 & (14.111) \\
\hline Family & & & & & 16.414 & (15.787) \\
\hline Other & & & & & 5.485 & $(9.757)$ \\
\hline Constant & -108.235 & $(67.233)$ & -13.011 & (73.219) & -17.689 & (67.989) \\
\hline$R^{2}$ & 0.011 & & 0.014 & & 0.020 & \\
\hline Observations & 3882 & & 3093 & & 3093 & \\
\hline Individuals & 905 & & 898 & & 898 & \\
\hline
\end{tabular}

FE is the fixed-effects estimator obtained on the balanced panel. $b$ are the point estimates and se the standard errors. Cluster-robust standard errors are used. $\mathrm{HH}$ and $\mathrm{CC}$ refers to household and credit card, respectively. Base category of categorical variables is lower than high school, unemployed, widowed, lower than 25 years, Asian, and ATM. Significance levels are denoted as ${ }^{* *} p<0.01,{ }^{* *} p<0.05,{ }^{*} p<0.1$ 
Table $\mathbf{2 7}$ FE regression results of contactless credit on cash share volume

\begin{tabular}{|c|c|c|c|c|c|c|}
\hline \multirow[b]{2}{*}{ Variable } & \multicolumn{2}{|l|}{$(1)$} & \multicolumn{2}{|l|}{ (2) } & \multicolumn{2}{|l|}{ (3) } \\
\hline & b & se & $\mathbf{b}$ & se & $\mathbf{b}$ & se \\
\hline Contactless credit & -0.011 & $(0.027)$ & -0.013 & $(0.030)$ & -0.013 & $(0.030)$ \\
\hline $\log ($ income) & -0.007 & $(0.013)$ & 0.007 & $(0.015)$ & 0.006 & $(0.015)$ \\
\hline Interest rate & 0.013 & $(0.010)$ & 0.013 & $(0.011)$ & 0.013 & $(0.011)$ \\
\hline \multicolumn{7}{|l|}{ Education } \\
\hline High school & $0.268^{* * *}$ & $(0.069)$ & $0.358^{* * *}$ & $(0.030)$ & $0.346^{* * *}$ & $(0.033)$ \\
\hline Some college & $0.308^{* *}$ & $(0.127)$ & $0.536^{* * *}$ & $(0.102)$ & $0.522^{* * *}$ & $(0.103)$ \\
\hline College & 0.160 & $(0.140)$ & $0.288^{* *}$ & $(0.119)$ & $0.277^{* *}$ & (0.119) \\
\hline Post graduate & 0.155 & $(0.166)$ & $0.281^{* *}$ & $(0.137)$ & $0.271^{* *}$ & $(0.135)$ \\
\hline \multicolumn{7}{|l|}{ Employment } \\
\hline Working & -0.011 & $(0.016)$ & -0.000 & $(0.018)$ & -0.002 & $(0.019)$ \\
\hline Retired & -0.005 & $(0.019)$ & -0.026 & $(0.027)$ & -0.027 & $(0.027)$ \\
\hline Other & -0.000 & $(0.020)$ & -0.036 & $(0.025)$ & -0.035 & $(0.025)$ \\
\hline \multicolumn{7}{|l|}{ Marital status } \\
\hline Single & 0.040 & $(0.060)$ & 0.031 & $(0.065)$ & 0.033 & $(0.064)$ \\
\hline Married & 0.008 & $(0.046)$ & 0.037 & $(0.050)$ & 0.039 & $(0.050)$ \\
\hline Separated & 0.026 & $(0.052)$ & 0.067 & $(0.054)$ & 0.068 & $(0.054)$ \\
\hline \multicolumn{7}{|l|}{ Age } \\
\hline $25-34$ & -0.073 & $(0.073)$ & $-0.296^{* * *}$ & $(0.102)$ & $-0.298^{* * *}$ & $(0.102)$ \\
\hline $35-44$ & -0.058 & $(0.078)$ & $-0.287^{* * *}$ & $(0.105)$ & $-0.289 * * *$ & $(0.105)$ \\
\hline $45-54$ & -0.090 & $(0.081)$ & $-0.320^{* * *}$ & $(0.108)$ & $-0.323^{* * *}$ & $(0.108)$ \\
\hline $55-64$ & -0.130 & $(0.083)$ & $-0.364^{* * *}$ & $(0.111)$ & $-0.365^{* * *}$ & $(0.111)$ \\
\hline$>65$ & -0.099 & $(0.087)$ & $-0.375^{* * *}$ & $(0.114)$ & $-0.375^{* * *}$ & $(0.114)$ \\
\hline \multicolumn{7}{|l|}{ Other } \\
\hline $\mathrm{HH}$ members & -0.004 & $(0.007)$ & 0.006 & $(0.008)$ & 0.006 & $(0.008)$ \\
\hline CC revolver & -0.006 & $(0.013)$ & -0.017 & $(0.015)$ & -0.016 & $(0.015)$ \\
\hline Home owner & -0.034 & $(0.022)$ & -0.032 & $(0.028)$ & -0.032 & $(0.028)$ \\
\hline \multicolumn{7}{|l|}{ Rel. characteristics } \\
\hline Security & & & -0.008 & $(0.006)$ & -0.008 & $(0.006)$ \\
\hline Setup & & & $0.023^{*}$ & $(0.013)$ & $0.023^{*}$ & $(0.013)$ \\
\hline Acceptance & & & -0.009 & $(0.016)$ & -0.009 & $(0.016)$ \\
\hline Costs & & & 0.011 & $(0.016)$ & 0.011 & $(0.016)$ \\
\hline Records & & & 0.010 & $(0.009)$ & 0.011 & $(0.009)$ \\
\hline Convenience & & & -0.003 & $(0.013)$ & -0.003 & $(0.013)$ \\
\hline \multicolumn{7}{|l|}{ Withdrawal method } \\
\hline Bank teller & & & & & 0.017 & $(0.017)$ \\
\hline Check casher & & & & & 0.003 & $(0.041)$ \\
\hline Cashback & & & & & -0.015 & $(0.015)$ \\
\hline Employer & & & & & 0.002 & $(0.039)$ \\
\hline Family & & & & & -0.009 & $(0.032)$ \\
\hline Other & & & & & -0.004 & $(0.027)$ \\
\hline Constant & 0.304 & $(0.192)$ & 0.229 & $(0.206)$ & 0.251 & $(0.207)$ \\
\hline$R^{2}$ & 0.013 & & 0.033 & & 0.035 & \\
\hline Observations & 3556 & & 2860 & & 2858 & \\
\hline Individuals & 852 & & 846 & & 845 & \\
\hline
\end{tabular}

FE is the fixed-effects estimator obtained on the balanced panel. $b$ are the point estimates and se the standard errors. Cluster-robust standard errors are used. $\mathrm{HH}$ and $\mathrm{CC}$ refers to household and credit card, respectively. Base category of categorical variables is lower than high school, unemployed, widowed, lower than 25 years, Asian, and ATM. Significance levels are denoted as ${ }^{* *} p<0.01,{ }^{* *} p<0.05,{ }^{*} p<0.1$ 
Table 28 FE regression results of contactless debit on cash share volume

\begin{tabular}{|c|c|c|c|c|c|c|}
\hline \multirow[b]{2}{*}{ Variable } & \multicolumn{2}{|l|}{ (1) } & \multicolumn{2}{|l|}{ (2) } & \multicolumn{2}{|l|}{ (3) } \\
\hline & b & se & b & se & b & se \\
\hline Contactless debit & -0.003 & $(0.033)$ & 0.003 & $(0.038)$ & 0.004 & $(0.038)$ \\
\hline $\log ($ income) & 0.015 & $(0.013)$ & 0.022 & $(0.014)$ & 0.020 & $(0.014)$ \\
\hline Interest rate & 0.012 & $(0.010)$ & 0.011 & $(0.010)$ & 0.011 & $(0.010)$ \\
\hline \multicolumn{7}{|l|}{ Education } \\
\hline High school & $0.269^{* * *}$ & $(0.067)$ & $0.357^{* * *}$ & $(0.029)$ & $0.344^{* * *}$ & $(0.032)$ \\
\hline Some college & $0.264^{*}$ & $(0.158)$ & $0.488^{* * *}$ & $(0.087)$ & $0.454^{* * *}$ & $(0.097)$ \\
\hline College & 0.090 & $(0.169)$ & $0.226^{* *}$ & $(0.109)$ & $0.195^{*}$ & $(0.116)$ \\
\hline Post graduate & 0.092 & $(0.185)$ & $0.211^{*}$ & $(0.125)$ & 0.181 & $(0.129)$ \\
\hline \multicolumn{7}{|l|}{ Employment } \\
\hline Working & -0.009 & $(0.014)$ & 0.009 & $(0.017)$ & 0.007 & $(0.017)$ \\
\hline Retired & -0.010 & $(0.017)$ & -0.033 & $(0.026)$ & -0.035 & $(0.026)$ \\
\hline Other & -0.016 & $(0.018)$ & -0.032 & $(0.023)$ & -0.031 & $(0.023)$ \\
\hline \multicolumn{7}{|l|}{ Marital status } \\
\hline Single & 0.013 & $(0.067)$ & 0.028 & $(0.072)$ & 0.027 & $(0.071)$ \\
\hline Married & 0.026 & $(0.055)$ & 0.053 & $(0.058)$ & 0.053 & $(0.057)$ \\
\hline Separated & 0.036 & $(0.058)$ & 0.077 & $(0.059)$ & 0.076 & $(0.058)$ \\
\hline \multicolumn{7}{|l|}{ Age } \\
\hline $25-34$ & -0.101 & $(0.063)$ & $-0.227^{*}$ & $(0.124)$ & $-0.227^{*}$ & $(0.124)$ \\
\hline $35-44$ & -0.093 & $(0.067)$ & $-0.222^{*}$ & $(0.126)$ & $-0.223^{*}$ & $(0.126)$ \\
\hline $45-54$ & -0.105 & $(0.070)$ & $-0.230^{*}$ & $(0.129)$ & $-0.233^{*}$ & $(0.129)$ \\
\hline $55-64$ & $-0.133^{*}$ & $(0.073)$ & $-0.260^{* *}$ & $(0.131)$ & $-0.261^{* *}$ & $(0.131)$ \\
\hline$>65$ & -0.101 & $(0.076)$ & $-0.253^{*}$ & $(0.133)$ & $-0.254^{*}$ & $(0.133)$ \\
\hline \multicolumn{7}{|l|}{ Other } \\
\hline $\mathrm{HH}$ members & 0.000 & $(0.007)$ & 0.004 & $(0.008)$ & 0.005 & $(0.008)$ \\
\hline CC revolver & -0.013 & $(0.012)$ & $-0.024^{*}$ & $(0.014)$ & -0.023 & $(0.014)$ \\
\hline Home owner & $-0.040^{*}$ & $(0.021)$ & -0.032 & $(0.026)$ & -0.031 & $(0.025)$ \\
\hline \multicolumn{7}{|l|}{ Rel. characteristics } \\
\hline Security & & & -0.009 & $(0.006)$ & -0.008 & $(0.006)$ \\
\hline Setup & & & 0.018 & $(0.012)$ & 0.018 & $(0.012)$ \\
\hline Acceptance & & & -0.006 & $(0.014)$ & -0.006 & $(0.014)$ \\
\hline Costs & & & 0.014 & $(0.015)$ & 0.013 & $(0.015)$ \\
\hline Records & & & 0.003 & $(0.009)$ & 0.003 & $(0.009)$ \\
\hline Convenience & & & 0.003 & $(0.012)$ & 0.004 & $(0.012)$ \\
\hline \multicolumn{7}{|l|}{ Withdrawal Method } \\
\hline Bank teller & & & & & 0.020 & $(0.016)$ \\
\hline Check casher & & & & & -0.017 & $(0.043)$ \\
\hline Cashback & & & & & -0.014 & $(0.015)$ \\
\hline Employer & & & & & 0.018 & $(0.040)$ \\
\hline Family & & & & & -0.015 & $(0.028)$ \\
\hline Other & & & & & -0.014 & $(0.025)$ \\
\hline Constant & 0.117 & $(0.213)$ & 0.006 & $(0.207)$ & 0.047 & $(0.210)$ \\
\hline$R^{2}$ & 0.013 & & 0.028 & & 0.030 & \\
\hline Observations & 3832 & & 3075 & & 3074 & \\
\hline Individuals & 905 & & 899 & & 898 & \\
\hline
\end{tabular}

FE is the fixed-effects estimator obtained on the balanced panel. $b$ are the point estimates and se the standard errors. Cluster-robust standard errors are used. $\mathrm{HH}$ and $\mathrm{CC}$ refers to household and credit card, respectively. Base category of categorical variables is lower than high school, unemployed, widowed, lower than 25 years, Asian, and ATM. Significance levels are denoted as ${ }^{* *} p<0.01,{ }^{* *} p<0.05,{ }^{*} p<0.1$ 


\section{Abbreviations}

ALP: American life panel; ATM: Automated teller machine; EMV: Europay international, MasterCard and VISA; EU: European union; FE: Fixed-effects; FED; Federal reserve system; GDP: Gross domestic product; LTP: Let's talk payments; NFC: Near-field communication; OLS: Ordinary least squares; PIN: Personal identification number; POS: Point-of-sale; SCPC: Survey of consumer payment choice; SPA: Smart payment association; USA: United States; USD: United States dollar

\section{Acknowledgements}

I would like to thank Martin Brown for his extremely valuable inputs and recommendations regarding the analysis in the paper. His comments helped to substantially improve the work. I am also grateful to the anonymous referees for their critical review, which has led to significant improvements of the paper.

\section{Authors' contributions}

Not applicable. There is only one author. The author(s) have read and approved the manuscript.

\section{Funding}

Not applicable.

\section{Availability of data and materials}

The datasets generated and/or analyzed during the current study are available from the Federal Reserve Bank of Atlanta, Consumer Payment Research Center, https://www.frbatlanta.org/banking-and-payments/consumerpayments/survey-of-consumer-payment-choice.

\section{Competing interests}

The author declares that he has no competing interests.

\section{Received: 21 January 2019 Accepted: 22 April 2020}

Published online: 01 June 2020

\section{References}

Alvarez, F., \& Lippi, F. (2009). Financial innovation and the transactions demand for cash. Econometrica, 77(2), 363-402

Amromin, G., \& Chakravorti, S. (2009). Whither loose change? The diminishing demand for small-denomination currency. Journal of Money, Credit and Banking, 41(2-3), 315-335.

Angrisani, M., Foster, K., Hitczenko, M. (2015). The 2013 survey of consumer payment choice: Technical appendix, Research Data Reports No. 15-5, Federal Reserve Bank of Boston. www.bostonfed.org. Accessed 10 May 2017 [Online].

Arango, C., Hogg, D., Lee, A. (2015). Why is cash (still) so entrenched? Insights from Canadian Shopping Diaries. Contemporary Economic Policy, 33(1), $141-158$.

Attanasio, O.P., Guiso, L., Jappelli, T. (2002). The demand for money, financial innovation, and the welfare cost of inflation: An analysis with household data. Journal of Political Economy, 110(21), 317-351.

Bagnall, J., Bounie, D., Huynh, K.P., Kosse, A., Schmidt, T., Schuh, S., Stix, H. (2016). Consumer cash usage: A cross-country comparison with payment diary survey data. International Journal of Central Banking, 12(4), 1-61.

Baumol, W.J. (1952). The transactions demand for cash: An inventory theoretic approach. The Quarterly Journal of Economics, 66(4), 545-556.

Borzekowski, R., \& Kiser, E.K. (2008). The choice at the checkout: Quantifying demand across payment instruments. International Journal of Industrial Organization, 26, 889-902.

Bouhdaoui, Y., \& Bounie, D. (2012). Modeling the share of cash payments in the economy. International Journal of Central Banking, 8(4), 175-195.

Briglevics, T., \& Schuh, S. (2013). U.S. consumer demand for cash in the era of low interest rates and electronic payments Working Paper No. 13-23, The Federal Reserve Bank of Boston.

Brits, H., \& Winder, C. (2005). Payments are no free lunch. DNB Occasional Studies, 3(2).

Chai, C. (2017). Contactless tap-and-go cards finally enter US market. www.creditcards.com. Accessed 10 Nov 2018 [Online].

Chen, H., Felt, M.H., Huynh, K.P. (2017). Retail payment innovations and cash usage: Accounting for attrition using refreshment samples. Journal of the Royal Statistical Society, Series A, Statistics in Society, 180(2), 503-530. https:// doi.org/10.1111/rssa.12208.
Ching, A.T., \& Hayashi, F. (2010). Payment card rewards programs and consumer payment choice. Journal of Banking and Finance, 34(8), 1773-1787.

Columba, F. (2009). Narrow money and transaction technology: New disaggregated evidence. Journal of Economics and Business, 61, 312-325.

Connolly, J., \& Stavins, J. (2015). Payment instrument adoption and use in the United States 2009-2013 by Consumers' Demographic Characteristics. Research Data Reports No. 15-6 Federal Reserve Bank of Boston.

Drehmann, M., Goodhart, C., Krueger, M. (2004). The challenges facing currency usage: will the traditional transaction medium be able to resist competition from new technologies? Economic Policy, 56, 195-227.

FED (2011). Federal Reserve System, The 2010 Federal Reserve Payments Study. www.federalreserve.gov. Accessed 11 Aug 2018 [Online].

FED (2014). Federal Reserve System, The 2013 Federal Reserve Payments Study. www.federalreserve.gov. Accessed 11 Aug 2018 [Online].

Foster, K., Schuh, S., Zhang, H. (2013). The 2010 Survey of Consumer Payment Choice. Research Data Reports No. 13-2, The Federal Reserve Bank of Boston.

Fujiki, H., \& Tanaka, M. (2014). Currency demand, new technology, and the adoption of electronic money: Micro evidence from Japan. Economics Letters, 125(1), 5-8.

Fung, B.S., Huynh, K.P., Sabetti, L. (2014). The impact of retail payment innovations on cash usage. Journal of Financial Market Infrastructures, 3(1), $1-29$.

van der Horst, F., \& Matthijsen, E. (2013). The irrationality of payment behaviour. DNB Occasional Studies, 11(4).

van Hove, L. (2008). On the war on cash and its spoils. International Journal of Electronic Banking, 1(1), 36-45.

Humphrey, D.B. (2004). Replacement of cash by cards in U.S. consumer payments. Journal of Economics and Business, 56, 211-225.

Huynh, K.P., Schmidt-Dengler, P., Stix, H. (2014). The role of card acceptance in the transaction demand for money. Working Paper No. 44, Bank of Canada.

Jonker, N. (2007). Payment instruments as perveived by consumers: Results from a household survey. De Economist, 155, 21-38.

von Kalckreuth, U., Schmidt, T., Stix, H. (2009). Choosing and using payment instruments: Evidence from German micro-data. Working Paper Series No. 1144 European Central Bank.

von Kalckreuth, U., Schmidt, T., Stix, H. (2014). Using cash to monitor liquidity Implications for payments, currency demand and withdrawal behavior. Journal of Money, Credit and Banking, 46(8), 1753-1785.

Kim, B.M., Yilmazer, T., Widdows, R. (2006). Adoption of internet banking and consumers' payment choices. Working Paper, Purdue University.

Klee, E (2006). Paper or Plastic? The effect of time on check and debit card use at grocery stores Working Paper, Board of Governors of the Federal Reserve System.

Lippi, F., \& Secchi, A. (2009). Technological change and the households' demand for currency. Journal of Monetary Economics, 56, 222-230.

LTP (2015). Let's Talk Payments Comprehensive 2015. U.S. Market Analysis of POS Terminals and EMV \& NFC Status Review.

McCallum, B.T., \& Goodfriend, M.S. (1987). Demand for money: Theoretical studies. In J. Eatwell, M. Milgate, P. Newman (Eds.), The New Palgrave: A Dictionary of Economics. Macmillan: Palgrave.

Polasik, M., Gorka, J., Wilczewski, G., Kunkowski, J., Przenajkowska, K., Tetkowska, N. (2013). Time efficiency of point-of-sale payment methods: Empirical results for cash, cards and mobile payments. In J. Cordeiro, L.A. Maciaszek, J. Filipe (Eds.), Enterprise Information Systems, Lecture Notes in Business Information Processing, Vol. 141 (pp. 306-320). Berlin Heidelberg: Springer.

SCF (2014). Survey of Consumer Finances, 2013 Survey of Consumer Finances. www.federalreserve.gov/econresdata/scf/scfindex.htm. Accessed 10 Oct 2015 [Online].

Schmiedel, H., Kostova, G.L., Ruttenberg, W. (2013). The social and private costs of retail payment instruments: A European Perspective. Journal of Financial Market Infrastructures, 2(1), 37-75.

Schuh, S., \& Stavins, J. (2013). How consumers pay: Adoption and use of payments. Accounting and Finance Research, 2(2), 1-21.

Schuh, S., \& Stavins, J. (2014). The 2011 and 2012 Survey of Consumer Payment Choice. Research Data Report No. 14-1, The Federal Reserve Bank of Boston.

Schuh, S., \& Stavins, J. (2015). The 2013 Survey of Consumer Payment Choice: Summary Results. Research Data Report No. 15-4, The Federal Reserve Bank of Boston. 
Snellman, J., Vesala, J., Humphrey, D.B. (2001). Substitution of noncash payment instruments for cash in Europe. Journal of Financial Services Research, 19(2/3), 131-145.

SPA (2016). Smart Payment Association, An Overview of Contactless Payment Benefits and Worldwide Developments. www.smartpaymentassociation.com. Accessed 20 Dec 2016 [Online].

Stix, H. (2003). How do debit cards affect cash demand? Survey Data Evidence. Working Paper 82 Oesterreichische Nationalbank.

Tobin, J. (1956). The interest elasticity of the transactions demand for cash. Review of Economics and Statistics, 38(3), 241-247.

\section{Publisher's Note}

Springer Nature remains neutral with regard to jurisdictional claims in published maps and institutional affiliations.

\section{Submit your manuscript to a SpringerOpen ${ }^{\circ}$ journal and benefit from:}

- Convenient online submission

- Rigorous peer review

- Open access: articles freely available online

- High visibility within the field

- Retaining the copyright to your article

Submit your next manuscript at $\gg$ springeropen.com 